\title{
Ortaokul Öğrencilerinin Fen Öğrenme Becerilerinin Çeşitli Değişkenlere Göre İncelenmesi*
}

\author{
Gülcan Özdemir**, Seda Çavuş Güngören ${ }^{* * * *}$, Funda Yeşildağ-Hasançebi*****
}

- Geliş Tarihi: 23.09.2020 • Kabul Tarihi: 31.05.2021 • Ç. Yayın Tarihi: 07.06.2021

$\ddot{\mathbf{O} z}$

Bu çalışmanın amacı, farklı sınıf düzeylerindeki öğrencilerin fen öğrenme becerilerinin çeşitli değişkenlere göre nasıl değiştiğini araştırmaktır. Ayrıca araştırma ortaokul öğrencileri ve fen bilimleri öğretmenlerinin fen dersinin Araştırma Sorgulamaya Dayalı Öğrenme (ASDÖ) açısından işıenişine yönelik görüşlerini belirlemeyi hedeflemektedir. Araştırmada açımlayıcı sıralı karma desen kullanılmıştır. Araştırmanın örneklemini farklı sınıf düzeylerinde öğrenim gören 805 ortaokul öğrencisi ve bu öğrencilerin fen bilgisi öğretmenleri $(n=4)$ oluşturmaktadır. Veriler Chang ve arkadaşları (2011) tarafından geliştirilen ve Türkçeye Şenler (2014) tarafından uyarlanan Fen Öğrenme Becerisi ölçeği, açık uçlu sorular ve yarı yapılandırılmış görüşmeler ile toplanmıştır. Verilerin analizinde nanparametrik testlerden Mann Whitney U Testi ve Kruskal Wallis uygulanmıştır. Açık uçlu sorular ve yarı yapılandırılmış görüşmelere ait veriler içerik analizi ile analiz edilmiştir. Araştırma sonucunda, öğrencilerin fen öğrenme beceri düzeylerinin ortalamanın üzerinde olduğu; cinsiyete göre farkl1lığın kız öğrenciler lehine olduğu; ebeveyn eğitim düzeyinin fen öğrenme becerisiyle ilişkili olduğu; fen başarısı yüksek olan öğrencinin fen öğrenme becerisi, bilimsel sorgulama ve iletişim yeterliklerinin yüksek olduğu; sınıf düzeyi arttıkça bilimsel sorgulama yeterliğinin düştüğü tespit edilmiştir. Öğretmen ve öğrencilerin fen bilimleri dersinin ASDÖ açısından işlenişine yönelik görüşlerinin hem birbirlerine hem de araştırmanın nicel verilerine ait sonuçlarına paralel olduğu belirlenmiştir.

Anahtar sözcükler: fen öğrenme becerisi, bilimsel sorgulama yeterliği, iletişim yeterliği, fen başarıs1, ebeveyn eğitim düzeyi

Atıf:

Özdemir, G., Çavuş Güngören, S. ve Yeşildağ-Hasançebi, F. (2022). Ortaokul öğrencilerinin fen öğrenme becerilerinin çeşitli değişkenlere göre incelenmesi. Pamukkale Üniversitesi Eğitim Fakültesi Dergisi, 54, 69-98. doi 10.9779/pauefd.799198.

\footnotetext{
* Bu çalışma birinci yazarın yüksek lisans tezinden üretilmiştir.

** Fen Eğitimi Uzman1, gulcan.akbayrak5@ gmail.com, ORCID ID: 0000-0002-5844-2501

*** Dr.Öğr.Üyesi, Çanakkale Onsekiz Mart Üniversitesi, sdacavus@ gmail.com, ORCID ID: 0000-0001-9521-0008

**** Dr.Öğr.Üyesi, Giresun Üniversitesi, fndysldg@gmail.com, ORCID ID: 0000-0001-9365-940X
} 


\section{Giriș}

Fen eğitiminin temel amaçlarından biri, araştıran ve sorgulayan bireyler yetiştirmektir (Milli Eğitim Bakanlığı [MEB], 2013, 2018). Birçok ülkenin (Amerika-NRC, 1996, 2000; Avustralya - Tytler, \& Hobbs, 2011; İngiltere - The National Curriculum in England, 2013) fen öğretim programında olduğu gibi ülkemizde de öğrencinin kendi öğrenmesinden sorumlu olması, sürece aktif katılması ve bilgiyi anlamlı, kalıcı olarak öğrenmesi hedeflenmiştir (MEB, 2018; Next Generation Science Standarts [NGSS], 2013). NSTA (2000) ve NGSS'nin (2013) yayınladığı fen eğitimi ölçütlerine göre okul öncesinden üniversiteye kadar tüm sınıf düzeyindeki öğrencilerin araştırma sorgulama sürecinde bilimsel araştırma yeteneğine sahip olup, bilimsel araştırmanın yapılma aşamalarını bilmeleri gerektiği yönünde açıklamalar yapılmıştır. Bu bağlamda fen bilimleri dersi öğretim programında sınıf ya da okul içinde, laboratuvar veya okul dışı öğrenme ortamlarında oluşturulan uygun etkinlikler, öğretim tasarımları ile Araştırma Sorgulamaya Dayalı Öğrenme (ASDÖ) yöntemine göre planlanması önerilmiştir (MEB, 2018: s.10). Alan yazında "inquiry based learning" olarak yer alan ASDÖ, araştırmacılar tarafından "bilimsel sorgulamaya dayalı öğrenme, araştırmaya dayalı öğrenme, sorgulamaya dayalı öğrenme, sorgulayıcı öğrenme, araştırma soruşturma tabanlı öğretim gibi farklı isimlerle Türkçeye çevrilerek günümüze kadar ulaşmıştır (Doğan, Han-Tosunoğlu, Özer \& Akkan, 2020; Taş, Başoğlu, Sarı̈öl, Tepe \& Güler, 2018)

Bybee (2000), bilimsel sorgulamanın üç unsurdan oluştuğunu öne sürmüştür: Bilimsel araştırma becerileri, bilimsel araştırma hakkında bilgi edinme ve fen içeriğini öğretmek için eğitici bir yaklaşım. Schwartz (2004) ise bilimsel sorgulamadan bilimsel bilginin geliştirildiği, kabul edildiği ve kullanıldığı süreçlerin özellikleri olarak bahsetmiştir. Sorgulamaya dayalı öğretim bireylerin; araştırma, inceleme ve bilgileri analiz etmelerini gerektiren bir öğrenme ortamı sağlamaktadır (Perry \& Richardson, 2001; Wu, \& Krajcik, 2006). Bu doğrultuda ASDÖ; bilimin doğasını da içinde barındıran öğrencilerin sahip oldukları ön bilgilerini, becerilerini kullanarak, bireysel veya grup olarak birer bilim insanı gibi düşünerek/çalışarak yani bilimsel bilgiyi açıklamak için bilimsel araştırma ve yöntemlerini kullanarak (Schwartz, 2004) öğrendikleri bir öğretim stratejisidir. Gözlemler yaparak, sorular oluşturarak, kitapları gözden geçirerek, araştırmaları planlayıp deneysel deliller dahilinde gözden geçirerek, verileri analiz edip yorumlayarak bir sonuca ulaşma süreci olarak tanımlanmıştır (National Research Council [NRC], 2000). Sorgulamaya dayalı öğrenme; temel araştırma becerilerinin yanında, bilimsel araştırma hakkındaki bilgili bir 
anlayış kazanma, bilimin diğer bilme yollarından ne kadar farklı olduğunu ve bilimsel bilginin nereden kaynaklandığını anlamalarını sağlamaktadır (Antink-Meyer, Bartos, Lederman, \& Lederman, 2016).

Fen Bilimleri Dersi Öğretim Programı, disiplinler arası bir anlayışla ASDÖ yaklaşımını temel alarak sınıf/okul içi ve okul dışı öğrenme ortamlarının tasarlanmasını hedeflenmektedir (MEB, 2018). ASDÖ sayesinde fen öğretiminin odağı değişmiş, fen ile ilgili olgu ve kavramların öğrenilmesinde ezberlemenin yerini bilimsel süreç becerilerinin ve eleştirel düşünme becerilerinin etkin olarak kullanılması almıştır (Açıkgöz \& Uluçınar Sağır, 2019). İlköğretim kademesinde fen eğitiminde bu yaklaşımın kullanılmasının amacı; öğrencilerin sorgulama, araştırma yapma ve bilimsel süreç becerilerini geliştirmelerine yardımcı olmaktır (Duban, 2008). Ancak Açıkgöz ve Uluçınar Sağır (2019) fen öğretmenlerinin araştırma sorgulamaya dayalı öğretime yönelik farkındalıklarını belirlemeye yönelik yaptıkları araştırmada öğretmenlerin sadece bir kısmının ASDÖ yaklaşımına yönelik program değişikliğinden haberdar oldukları ve haberdar olanların da net bir bilgiye sahip olmadığı belirlenmiştir. Ayrıca az sayıda öğretmenin araştırma sorgulamaya dayalı öğretim yaklaşımını sınıflarında uygulamaya çalıştıkları ancak eksik donanım, yeterli sürenin olmaması, sınıf mevcudunun fazla olması gibi faktörlerin uygulamaları zorlaştırdığı ve öğrencilerin verilen görevleri kısmen yerine getirebildikleri tespit edilmiştir. Bu sonuç fen bilimleri öğretim programı ile hedeflenen öğrenci profili (okuyan, eleştiren sorgulayan vb.) açısından önemlidir.

Öğrencilerin bilimi daha iyi anlayabilmeleri için belirli problemler hakkında nasıl soru soracaklarını, veri ve delilleri temel alarak bu soruları nasıl cevaplayacaklarını öğrenmeleri gerekir. Bu süreci yaşayan öğrenciler araştırmaya farklı kaynaklardan deliller bulmayı, argümanlar oluşturmayı, mevcut bilgilere dayanarak açıklamalar yapmayı ve sonuçları iletmeyi ve savunmayı öğrenirler (Chang ve diğerleri, 2011). Bu doğrultuda fen dersleriyle öğrencilere bu becerilerin nasıl kazandırıldığı önemlidir. Literatürde sorgulamaya dayalı öğretimin öğrenmeye olan etkisini araştıran pek çok araştırma (Abd-El-Khalick, Boujaoude, Duschl, Lederman vd. 2004; Bilir \& Özkan, 2018; Cairns \& Areepattamannil, 2019; Keçeci, 2014; Timur \& Kıncal, 2010; Varlı \& Uluçınar Sağır, 2019) yapılmıştır. Örneğin, Timur ve Kıncal, (2010) sorgulamalı öğretimin, geleneksel yöntem ile karşılaştırıldığında öğrencilerin "bilgi”" düzeyindeki başarılarını etkilemediğini, fakat "kavrama", "uygulama" ve "genel başarı" düzeylerini anlamlı ölçüde değiştirdiğini belirtmişlerdir. Bilir ve Özkan, (2018) araştırmaları sonucunda ASDÖ yaklaşımının 
uygulandığ1 fen öğretiminde öğrencilerin derse karşı daha ilgili oldukları, el becerilerinin geliştiği, yaparak yaşayarak daha iyi öğrendikleri, merak duygularının arttığı, öğrenmeleri sırasında eğlendikleri ve derse daha aktif şekilde katıldıklarını belirtirken, Keçeci, (2014) ASDÖ’nün öğrencilerin bilimsel süreç becerilerinin geliştirilmesinde etkili olduğu sonucuna varmıştır.

Bilimsel süreç becerileri kazanımının yanında bu kazanımları paylaşmak ve bilimi daha ileriye taşımak için bilimsel iletişim becerisine sahip olmak fen öğretiminin önemli kazanımlarındandır. Okuma ve yazma, fikir alışverişinde bulunma, bilimsel tartışmalar yapma gibi süreçler bu iletişim becerilerini kullanmayı gerektirir. Chang ve arkadaşları (2011) Organization for Economic Cooperation and Development (OECD, 2005) raporunda, öğrencilerin becerilerinin değerlendirilmesi sürecinde sadece temel alan bilgisi değil beceri ve bilgi uygulamaları ile bilimdeki iletişim yeteneğini de kapsayan fen öğrenme becerilerinin değerlendirilmesi gerektiğini belirtmişlerdir. Dolayısıyla bilimsel iletişimin fen öğrenme becerileri içerisinde önemli bir yere sahip olduğu dikkat çekmektedir. Nitekim Wildan, Hakim, Siahaan ve Anwar'ın (2019) deneysel çalışmasında sorgulama yaklaşımının öğrencilerin iletişim becerileri üzerinde olumlu bir etkisi olduğu, deney grubunun yazma, sözlü ve sosyal becerilerdeki puanlarının kontrol grubundan daha yüksek olduğu belirlenmiştir. Ulusal anlamda sınırlı sayıda araştırmacının fen öğrenme becerisi ve iletişim konusunda araştırma yaptığı gözlenmiştir (Aslan-Efe \& Özmen, 2018; Duran, 2014; Şenler, 2014). Dolayısıyla öğrenen üzerinde çeşitli olumlu etkileri ifade edilen bu yöntem konusunda araştırma yapılmasına hala ihtiyaç vardır (Doğan ve diğerleri, 2020). Araştırmacılar, ASDÖ üzerine Türkiye'de az çalışılmış bir araştırma alanı olduğunu, yapılan çalışmalarda daha çok nicel yöntemlerin tercih edildiğini, karma yöntem kullanılan çalışmaların az ve nitel yöntemlere araştırmalarda yeterli yer verilmediğine dikkat çekmiştir (Kızılaslan, Sözbilir \& Yaşar, 2012). Araştırma sorgulamaya dayalı öğretimin okullarda etkili bir şekilde uygulanabilmesi için bu yaklaşımın derinlemesine incelendiği araştırmalar öğretmenlere yol gösterecektir. ASDÖ üzerine yapılan araştırmaların çoğunlukla akademik başarıya etkinin incelendiği, örneklem olarak öğretmen adaylarının seçildiği deneysel araştırmalar göze çarpmaktadır (Alemli, 2019). ASDÖ’nün etkililiğinin farklı değişkenler ile ortaokul seviyesinde araştırıldığı çalışmalar incelendiğinde araştırmaların akademik başarı, kavramsal anlama, bilimsel süreç becerileri ve argüman geliştirme düzeyleri konusunda yoğunlaştığı dikkat çekmektedir (Bilir \& Özkan, 2018; Duran \& Dökme, 2018; Varlı \& Uluçınar Sağır, 2019). Alan yazındaki birçok çalışma ASDÖ yaklaşımının öğrencilerin fen 
öğrenmede akademik başarını artırdığını vurgularken bu yaklaşımın öğrencilerin fen öğrenme becerilerini nasıl etkilediği üzerine araştırmalara rastlanmamıştır. Ayrıca, Varlı ve Uluçınar Sağır (2019) ASDÖ’nün öğrencilerin farklı becerileri üzerine etkilerinin araştırılmasını önermektedir. Bu araştırma ile ASDÖ yaklaşımının öğrencilerin fen öğrenme becerilerini nasıl etkilediğinin çeşitli değişkenler (cinsiyet, sınıf düzeyi, anne ve baba eğitim düzeyi, öğrencinin fen dersi başarısı) açısından incelenmesinin alan yazına katkı sağlayacağı düşünülmektedir. Alan yazında fen öğrenme becerisinin benzer değişkenler açısından incelendiği sınırlı araştırmanın olduğu belirlenmiştir (Aslan-Efe \& Özmen, 2018). Ayrıca fen öğrenme becerisine katkı sunan ASDÖ’nün fen bilimleri derslerinde nasıl kullanıldığının öğretmen ve öğrenci görüşleri aracılığıyla değerlendirilmesi açısından önemlidir. Bu kapsamda araştırma soruları aşağıdaki gibi belirlenmiştir:

1. Ortaokul öğrencilerinin fen öğrenme beceri düzeyleri nasıldır?

2. Ortaokul öğrencilerinin fen öğrenme becerileri cinsiyete göre farklılık gösterir mi?

3. Ortaokul öğrencilerinin fen öğrenme becerileri sınıf düzeyine göre farklılık gösterir mi?

4. Ortaokul öğrencilerinin fen öğrenme becerileri, öğrencilerin anne ve babalarının eğitim düzeyine göre farkl1lık gösterir mi?

6. Ortaokul öğrencilerinin fen öğrenme becerileri fen bilimleri dersi başarı notuna göre farklılık gösterir mi?

7. Ortaokul öğrencilerinin ASDÖ açısından fen dersinin işlenişiyle ilgili görüşleri nelerdir?

8. Fen bilimleri öğretmenlerinin ASDÖ açısından fen dersinin işlenişiyle ilgili görüşleri nelerdir?

\section{Yöntem}

\section{Araştırmanın Modeli}

$\mathrm{Bu}$ araştırmada, karma araştırma yöntemlerinden açımlayıcı sıralı desen kullanılmıştır. Karma yöntem araştırması, nitel ve nicel araştırmaya dayalı entelektüel ve pratik bir sentezdir; üçüncü metodolojik (nitel ve nicel araştırmalarla birlikte) veya araştırma paradigmasıdır (Johnson, Onwuegbuzie \& Turner, 2007). Dolayısıyla nitel ve nicel yöntemin bir arada kullanıldığı bir yöntemdir (Yıldırım \& Şimşek, 2018: s.322). Bu yöntemin çeşitlerinden olan açımlayıcı sıralı desen iki farklı etkileşimli aşamadan oluşmuş olup, birincil öncelikle nicel verilerin toplanması ve çözümlenmesi ile başlayıp nitel verilerin toplanması ve çözümlenmesi ile devam etmektedir (Creswell \& Plano-Clark, 2014, 
s.80). Araştırmada nitel veriler, baskın olan nicel araştırmalardan tarama yöntemi içindeki ikincil araştırma sorusunu cevaplarken sürece katılmıştır (Creswell \& Plano Clark, 2014). Uygulama öncesinde il milli eğitim müdürlügüünden gerekli izinler alınmış, yayın etiğine uygun bir araştırma süreci takip edilmiştir.

\section{Çalışma Grubu}

Araştırmanın çalışma grubunun seçiminde sıralı karma yöntem örneklemi kullanılmıştır. Baki ve Gökçek, (2012) sıralı karma yöntemin olasılıklı ve amaçlı örnekleme stratejilerinin (Nicel-Nitel) sırası ile kullanıldığını ve karma yöntem araştırmalarında en sık kullanılan yöntemlerden biri olduğunu ifade etmiştir. $\mathrm{Bu}$ örnekleme yönteminde sirasıyla nicel aşamaya olasılıklı örneklem belirleme yöntemleriyle katılan örneklemin belirlenmesi, daha sonra bu örneklem içerisinden de amaçlı örnekleme yöntemiyle nitel aşamaya katılacak örneklem seçimi yapılır (Baki \& Gökçek, 2012). Araştırmanın çalışma grubunu araştırmacıların da yaşadığı Türkiye'nin kuzeydoğusunda bir il merkezindeki okullar arasından olasılıklı örnekleme yöntemi ile belirlenen altı farklı devlet okulunda farklı sınıf düzeylerinde öğrenim gören 805 ortaokul öğrencisi (\%53’ü k1z, \%47‘si erkek) oluşturmaktadır. Araştırmanın çalışma grubunda 195 beşinci sınıf, 194 altıncı sınıf, 225 yedinci sınıf ve 190 sekizinci sınıf öğrencisi yer almaktadır. Bu öğrencilerin dersine giren mesleki deneyimleri 5-10 yıl arasında olan ve araştırmaya gönüllü olarak katılan dört fen bilimleri öğretmeni katılmıştır. Araştırmaya öğrencilerle birlikte öğretmenlerin dahil edilmesinin sebebi ASDÖ açısından fen dersinin işlenişine dair elde edilecek verilerin sadece öğrencilerin bakış açıları ile değil aynı zamana dersin diğer önemli paydaşı olan öğretmenlerin fikirleri ile zenginleştirilebileceği düşüncesidir.

\section{Çalışmada Kullanılan Veri Toplama Araçları}

Araştırma verileri bir nicel iki nitel veri toplama araciyla elde edilmiştir. Nicel veriler Chang ve arkadaşları (2011) tarafından geliştirilen, Şenler (2014) tarafından Türkçe' ye uyarlanan 5'li likert tipi “Fen Öğrenme Becerisi Ölçeği” aracılığı ile toplanmıştır. Şenler'in çalışma grubu öğretmen adaylarıdır. Ancak ölçeğin ilköğretimden üniversiteye olan tüm öğrencilerin bilimsel sorgulama ve iletişim becerilerini ölçmede kullanılabileceğini belirtmiştir (Şenler, 2014, s.403). Ölçekte yer alan sorular bilimsel sorgulama ve iletişim olmak üzere iki alt ölçekten ve toplam 29 maddeden oluşmaktadır. Bilimsel sorgulama alt ölçeğinin soru ve hipotez önerme, planlama, deney yapma ve veri toplama, veri analizi ve yorumlama; iletişim alt ölçeğinin ise ifade etme, değerlendirme, etkileşimde bulunma ve müzakere etme olmak 
üzere dörder alt boyutu vardır. Öğrencilere ölçeği cevaplamaları için bir ders saati süre verilmiştir.

Nitel verilerin elde edilmesi için açık uçlu sorulardan oluşan görüş formu ve yarı yapılandırılmış mülakat kullanılmıştır. Görüş formu ve yarı yapılandırılmış mülakat soruları fen öğrenme becerisi ölçeğinin boyutlarından yararlanılarak bir fen bilgisi öğretmeni ve iki fen eğitimi uzmanı tarafından geliştirilmiş ve pilot çalışması yapılmıştır. Ayrıca görüş formu geliştirilirken 2018 fen bilimleri öğretim programı çerçevesinde veri, değişkenlerin belirlenmesi, hipotez kurma kavramlarının dördüncü ve beşinci sınıf kazanımlarında yer verildiği belirlenmiştir. Bu kapsamda veri toplanan okullardan seçilen 60 ortaokul öğrencisi ile açık uçlu soruların yer aldığı görüş formu aracılı̆̆ıyla veriler toplanmıştır. Öğrenci görüşlerini alırken katılımcı sayısı fazla olduğundan görüş formu kullanılmıştır. Açık uçlu soruların yer aldığı formda öğrenciler için; deneyi planlama ve hazırlık süreci (bir soru), deney yapma (bir soru), verileri kaydetme (bir soru), veri analizi (bir soru), deney öncesi ve sonrası fikirlerin karşılaştırılması (bir soru) ve sonuçların paylaşılması (bir soru) süreçlerine yönelik altı soru yer almaktadır.

Yarı yapılandırılmış mülakatlar ise bu formu dolduran öğrencilerin fen bilimleri dersine giren dört fen bilimleri öğretmeni ile yapılmıştır. Mülakat sorularının içeriği öğrencilere yöneltilen soruların paralelinde ancak daha fazla ayrıntıya ulaşılması için toplam dokuz soru olarak hazırlanmıştır. Öğretmenlere yöneltilen yarı yapılandırılmış görüşmelerde; deneyi planlama ve hazırlık süreci (bir soru), deney yapma (bir soru), verileri kaydetme (bir soru), veri analizi ve yorumlama (iki soru), verileri sunma (bir soru), deney öncesi ve sonrası fikirleri karşılaştırma (bir soru), paylaşma (iki soru) süreçlerine yönelik sorular yöneltilmiştir. Öğrencilerin formu doldurmak için verilen süre ve öğretmenler ile yapılan yüz yüze görüşmeler ortalama 30-40 dakika sürmüştür.

\section{Veri Analizi}

Fen öğrenme becerisi ölçeği 5=Kesinlikle Katılıyorum, 4=Katılıyorum, 3=Kararsızım, 2=Katılmıyorum ve $1=$ Kesinlikle Katılmıyorum şeklinde puanlanmıştır. Ölçeğin maddetoplam korelasyonları hesaplanmış ve korelasyon değerleri 0,42 ile 0,70 arasında olduğu görülmüştür. Madde ayırt edicilik özelliği için \%27 alt ve üst grup ortalamaları bağımsız ttesti ile karşılaştırılmış olup tüm test maddeleri için $\mathrm{p}<.001$ düzeyinde anlamlı olduğu belirlenmiştir. Bilimsel sorgulama ile iletişim alt ölçekleri arasındaki korelasyon değeri 0,77 olup $\mathrm{p}<.001$ düzeyinde anlamlı olduğu saptanmıştır. Yapılan faktör analizi sonucunda uyum indeksleri değerlerinin kabul edilebilir değer sınırlar içinde olduğu tespit edilmiştir. Veriler 
SPSS 20 istatistik programında analiz edilmiştir. Ölçekten elde edilen verilerin normallik analizi için grafikler (Q-Q grafiği ve kutu-bıyık grafik) incelenip Kolmogorov-Smirnov testi uygulanmış ve test sonucunda verilerin normal dağılmadığı $(\mathrm{p}<.05)$ tespit edilmiştir. Parametrik testlerin varsayımlarından "verilerin normal dağılması” şartı sağlanamadığından veri analizinde nanparametrik testler tercih edilmiştir. $\mathrm{Bu}$ bağlamda araştırmada nanparametrik testlerden Mann Whitney U Testi ve Kruskal Wallis testi uygulanmıştır. Ölçekten elde edilen sonuçların güvenilirliği incelendiğinde Şenler'in (2014) Cronbach’s Alpha katsayılarını bilimsel sorgulama alt ölçeği için .90, iletişim alt ölçeği için .92 ve toplam ölçek için 95 olarak hesapladığı gözlenmiştir. Bu araştırmada Cronbach's Alpha katsayıları bilimsel sorgulama alt ölçeği için .86, iletişim alt ölçeği için .87 ve toplam ölçek için .92 olarak tespit edilmiştir.

Araştırmanın nitel boyutunda içerik analizi kullanılmıştır. İçerik analizi sözel, yazılı ve diğer materyallerin derin bir şekilde ve sistemli olarak incelenmesini sağlayan bir yaklaşımdır. İçerik analizinin aşamaları dört basamak halinde belirtilmiştir. Bunlar: veri kodlama, tema oluşturma, düzenleme ve yorumlama şeklindedir (Yıldırım \& Şimşek, 2018: s.243). Bu kapsamda açık uçlu sorular içeren form aracılığıyla öğrencilerden elde edilen veriler kodlanarak ortak bir tema altında birleştirilmiştir. Öğretmenlerle yapılan mülakatlarda ise ses kayıtları dinlenerek transkript edilmiş ve sorulan sorulara verilen cevaplar kodlanarak analiz edilmiştir. Verilerin iç geçerliği için uzun süreli etkileşim, derin odaklı veri toplama, çeşitleme, uzman incelemesi ve mülakatlar sırasında katılımcı teyidi yapılmıştır. Dış geçerlik için nicel verilerin elde edildiği gruba ait katılımcılardan seçilmiş öğrencilerle ve onların öğretmenleri olacak şekilde amaçlı bir örneklem seçimi yapılmış ve ayrıntılı betimlemelere yer verilmiştir. İç güvenirlik için verilerin toplanması sürecinde tutarlı davranılmış ve tüm katılımcılar ile aynı soruların sorulması, analizinde ise yine tutarlı kodlama yapılmasına dikkat edilmiştir. Dış güvenirlik uzman teyidi ve bire bir alıntı yani örnek söylemlerin sunumu ile sağlanmıştır. 


\section{Bulgular}

\section{Ortaokul Öğrencilerinin Fen Öğrenme Beceri Düzeyleri}

Araştırmada ortaokul öğrencilerinin fen öğrenme beceri düzeyleri bilimsel sorgulama, iletişim alt ölçeğine göre analiz edilmiştir. İlgili sonuçlar Tablo 1'de sunulmuştur.

Tablo 1. Ortaokul Öğrencilerinin Fen Öğrenme Beceri Düzeyleri

\begin{tabular}{|c|c|c|c|c|}
\hline Alt Ölçek & Alt Boyut & $\mathrm{N}$ & $\overline{\mathrm{x}}$ & ss \\
\hline \multirow{4}{*}{$\begin{array}{l}\text { Bilimsel } \\
\text { sorgulama }\end{array}$} & Soru ve hipotez önerme & 805 & 4.21 & .60 \\
\hline & Planlama & 805 & 4.00 & .72 \\
\hline & $\begin{array}{l}\text { Deney yapma ve veri } \\
\text { toplama }\end{array}$ & 805 & 4.09 & .77 \\
\hline & $\begin{array}{l}\text { Veri analizi ve } \\
\text { yorumlama }\end{array}$ & 805 & 4.08 & .68 \\
\hline \multirow[t]{4}{*}{ İletişim } & İfade etme & 805 & 4.03 & .73 \\
\hline & Değerlendirme & 805 & 4.16 & .66 \\
\hline & Etkileşimde bulunma & 805 & 4.15 & .73 \\
\hline & Müzakere etme & 805 & 4.17 & .70 \\
\hline
\end{tabular}

Tablo 1 incelendiğinde öğrencilerinin fen öğrenme beceri düzeylerinin bilimsel sorgulama ve iletişim alt ölçeklerine ait ortalamaların dördün üzerinde olduğu tespit edilmiştir.

\section{Ortaokul Öğrencilerinin Fen Öğrenme Becerilerinden Bilimsel Sorgulama ve İletişim Yeterliklerinin Cinsiyet Değişkenine Göre İncelenmesi}

Araştırmada ortaokul öğrencilerinin fen öğrenme beceri düzeyleri cinsiyet değişkeni açısından incelenmiş ve farklılık gösterdiği belirlenmiştir. İlgili sonuçlar Tablo 2'de sunulmuştur. 
G, Özdemir, S, Ç. Güngören ve F, Y.Hasançebi / Pamukkale Üniversitesi Eğitim Fakültesi Dergisi, 54, 69-98, 2022

Tablo 2. Fen Öğrenme Becerilerinin Cinsiyet Değiş̧kenine Göre Karşılaştırılması

\begin{tabular}{|c|c|c|c|c|c|c|c|}
\hline Alt Ölçek & $\begin{array}{c}\text { Cinsiyet } \\
*\end{array}$ & $\mathrm{~N}$ & $\begin{array}{c}\text { Sira } \\
\text { ortalamas1 }\end{array}$ & $\begin{array}{c}\text { Sira } \\
\text { toplamı }\end{array}$ & $U$ & $\mathrm{Z}$ & $\mathrm{p}$ \\
\hline Öğrenme & $\mathrm{K}$ & 427 & 423.20 & 180704.50 & 71652.50 & -2.689 & .00 \\
\hline Becerisi & E & 377 & 379.06 & 142905.50 & & & \\
\hline Bilimsel & $\mathrm{K}$ & 427 & 420.65 & 179619.00 & 72738.00 & -2.36 & .01 \\
\hline Sorgulama & $\mathrm{E}$ & 377 & 381.94 & 143991.00 & & & \\
\hline \multicolumn{8}{|l|}{ Boyutu } \\
\hline Soru ve & K & 427 & 402.75 & 171972.50 & 80594.50 & -.03 & .97 \\
\hline hipotez & $\mathrm{E}$ & 378 & 403.29 & 152442.50 & & & \\
\hline \multicolumn{8}{|l|}{ önerme } \\
\hline \multirow{2}{*}{ Planlama } & $\mathrm{K}$ & 427 & 413.88 & 176726.50 & 75630.50 & -1.49 & .14 \\
\hline & $\mathrm{E}$ & 377 & 389.61 & 146883.50 & & & \\
\hline Deney yapma & $\mathrm{K}$ & 427 & 430.96 & 184019.50 & 68764.50 & -3.67 & .00 \\
\hline $\begin{array}{l}\text { ve veri } \\
\text { toplama }\end{array}$ & $\mathrm{E}$ & 378 & 371.42 & 140395.50 & & & \\
\hline Veri analizi & $\mathrm{K}$ & 427 & 416.39 & 177800.50 & 74983.50 & -1.75 & .08 \\
\hline ve & $\mathrm{E}$ & 378 & 387.87 & 146614.50 & & & \\
\hline \multicolumn{8}{|l|}{ yorumlama } \\
\hline İletişim & $\mathrm{K}$ & 427 & 425.66 & 181758.00 & 71026.00 & -2.94 & .00 \\
\hline Boyutu & $\mathrm{E}$ & 377 & 377.40 & 142657.00 & & & \\
\hline \multirow{2}{*}{ İfade etme } & $\mathrm{K}$ & 427 & 407.39 & 174111.50 & 7862.50 & -.621 & .53 \\
\hline & $\mathrm{E}$ & 378 & 387.87 & 150303.50 & & & \\
\hline \multirow{2}{*}{ Değerlendirme } & $\mathrm{K}$ & 427 & 413.18 & 176426.50 & 76357.50 & -1.33 & .18 \\
\hline & $\mathrm{E}$ & 378 & 391.50 & 147988.50 & & & \\
\hline \multirow{2}{*}{$\begin{array}{l}\text { Etkileşimde } \\
\text { bulunma }\end{array}$} & K & 427 & 424.08 & 181082.50 & 71701.0 & -2.77 & .00 \\
\hline & $\mathrm{E}$ & 378 & 379.19 & 143332.50 & & & \\
\hline \multirow{2}{*}{ Müzakere etme } & $\mathrm{K}$ & 427 & 434.68 & 185609.50 & 67174.50 & -4.14 & .00 \\
\hline & $\mathrm{E}$ & 378 & 367.21 & 138805.50 & & & \\
\hline
\end{tabular}

$*_{\mathrm{K}}: \mathrm{K} 1 \mathrm{Z}$ E: Erkek

Tablo 2 incelendiğinde Mann Whitney U testi sonuçlarına göre kız öğrencilerin fen ögrenme becerisi puanlarının sıra ortalamaları (423.20) ile erkek öğrencilerin sıra ortalamaları (379.06) arasında istatistiksel olarak anlamlı bir farklılık tespit edilmiştir [U= 
71652.5, p<.05]. Bu farklılığın da sıra ortalama puanları karşılaştırıldığında kız öğrencilerin lehine olduğu anlaşılmaktadır. Fen beceri ölçeğinin alt ölçekleri ayrı ayrı incelendiğinde ise öğrencilerin bilimsel sorgulama ölçeğinden aldıkları puanların [U=72738.00, $\mathrm{p}<.05]$ ve iletişim ölçeğinden aldıkları puanların $[\mathrm{U}=71026.00, \mathrm{p}<.05]$ yine kız öğrencilerin lehine farkl1lık gösterdiği belirlenmiştir.

Bilimsel sorgulama alt ölçeğinin alt boyutları ayrı ayrı incelendiğinde sadece kız öğrencilerin deney yapma ve veri toplama sıra ortalamaları (430.96) ve erkek öğrencilerin deney yapma ve veri toplama sıra ortalamaları (371.42) arasında istatistiksel olarak anlamlı bir farkl1lık olduğu görülmektedir [U=68764.50, p<.05]. İletişim alt ölçeğinde yer alan alt boyutlar ayrı ayrı incelendiğinde sadece iki alt boyutta anlamlı farklılık olduğu belirlenmiştir. Kız öğrencilerin etkileşimde bulunma sıra ortalamaları (424.08) ve erkek öğrencilerin etkileşimde bulunma sıra ortalamaları (379.19) arasında istatistiksel olarak kız öğrencilerin lehine anlamlı bir farklılık tespit edilmiştir [U=71701.0, $\mathrm{p}<.05]$. Benzer şekilde k1z öğrencilerin müzakere etme sıra ortalamaları (434.68) ile erkek öğrencilerin sıra ortalamaları (367.21) arasında istatistiksel olarak kız öğrencilerin lehine anlamlı bir farklılık olduğu belirlenmiştir [U=67174.50, $\mathrm{p}<.05]$.

\section{Ortaokul Öğrencilerinin Fen Öğrenme Becerilerinin Sınıf Düzeyi Açısından Íncelenmesi}

Ortaokul öğrencilerinin fen öğrenme becerileri sınıf düzeyi açısından incelenmiş ve karşılaştırma sonuçlarına göre bilimsel sorgulama alt boyutunun sınıf düzeyine göre farklılık gösterdiği belirlenmiştir. İlgili sonuçlar Tablo 3’te sunulmuştur. 
Tablo 3. Ortaokul öğrencilerinin fen ögrenme becerilerinin sınıf düzeyi açısından incelenmesi

\begin{tabular}{|c|c|c|c|c|c|c|c|}
\hline Ölçekler & $\begin{array}{c}\text { Sinıf } \\
\text { Düzeyi }\end{array}$ & $\mathrm{N}$ & $\begin{array}{c}\text { Sira } \\
\text { ortalamas1 }\end{array}$ & $X^{2}$ & $\mathrm{sd}$ & $\mathrm{p}$ & $\begin{array}{l}\text { Anlamlı } \\
\text { Farklılık }\end{array}$ \\
\hline Fen Öğrenme & 5 & 194 & 430.68 & & & & \\
\hline \multirow[t]{3}{*}{ Becerisi } & 6 & 196 & 414.08 & & & & \\
\hline & 7 & 224 & 317.84 & 7.320 & 3 & .06 & \\
\hline & 8 & 190 & 397.93 & & & & \\
\hline \multirow{4}{*}{$\begin{array}{l}\text { Bilimsel } \\
\text { sorgulama alt } \\
\text { boyutu }\end{array}$} & 5 & 15 & 442.59 & & & & \multirow{4}{*}{$\begin{array}{l}7<5 \\
8<5\end{array}$} \\
\hline & 6 & 24 & 409.69 & & & & \\
\hline & 7 & 75 & 364.92 & 11.907 & 3 & .00 & \\
\hline & 8 & 174 & 398.47 & & & & \\
\hline İletişim alt & 5 & 15 & 416.51 & & & & \\
\hline \multirow[t]{3}{*}{ boyutu } & 6 & 24 & 416.24 & & & & \\
\hline & 7 & 75 & 384.92 & 2.878 & 3 & .41 & \\
\hline & 8 & 174 & 397.98 & & & & \\
\hline
\end{tabular}

Tablo 3 incelendiğinde öğrencilerin fen becerileri arasında sınıf düzeyi açısından anlamlı bir fark olmadığ ${ }_{1}\left(x^{2}(3)=7.320, p>05\right)$, ölçeğin iletişim alt boyutunda sınıf düzeyine göre anlamlı fark olmadığ $1\left(\mathrm{x}^{2}(3)=2.878, \mathrm{p}>.05\right)$ ancak bilimsel sorgulama alt boyutunda artan sınıf düzeyi lehine anlamlı fark olduğu $\left(x^{2}(3)=11.907, p<.05\right)$ tespit edilmiştir. 8. sınıf ile 5. sınıf öğrencileri arasında ve 7. sınıf ile 5. sınıf öğrencileri arasında alt sinıf düzeyinin lehine anlamlı fark tespit edilmiştir.

\section{Ortaokul Öğrencilerinin Fen Öğrenme Becerisinin Anne Eğitim Durumuna Açısından İncelenmesi}

Ortaokul öğrencilerinin fen becerileri anne eğitim durumuna göre incelendiğinde istatistiksel olarak anlamlı farklar belirlenmiştir. Sonuçlar Tablo 4’te verilmiştir.

Tablo 4.Ortaokul Öğrencilerinin Fen Ögrrenme Becerisinin Anne Ĕ̈itim Durumuna Göre Incelenmesi

$\begin{array}{llllllll}\text { Ölçekler } & \text { Eğitim } & N & \text { Sıra } & X^{2} & s & p & \text { Anlamlı }\end{array}$




\begin{tabular}{|c|c|c|c|c|c|c|c|}
\hline & durumu & & ortalamas1 & & $\mathrm{d}$ & & farklilık \\
\hline \multirow{5}{*}{$\begin{array}{l}\text { Fen Öğrenme } \\
\text { becerisi }\end{array}$} & 1.İlkokul & 173 & 366.37 & \multirow{5}{*}{37.50} & \multirow{5}{*}{4} & \multirow{5}{*}{.00} & \multirow{5}{*}{$\begin{array}{l}3>1,4>1, \\
5>1,3>2,4>2, \\
5>2,5>3,5>4\end{array}$} \\
\hline & 2.Orta okul & 189 & 337.34 & & & & \\
\hline & 3.Lise & 233 & 450.63 & & & & \\
\hline & 4.Üniversite & 175 & 424.19 & & & & \\
\hline & 5.Lisans üstü & 34 & 507.07 & & & & \\
\hline \multirow{6}{*}{$\begin{array}{l}\text { Bilimsel } \\
\text { sorgulama } \\
\text { ölçeği }\end{array}$} & & & 267 & \multirow{6}{*}{38.581} & \multirow{6}{*}{4} & \multirow{6}{*}{.00} & $3>1,4>1,5>1$ \\
\hline & 1.MNOKL & (17) & 301 & & & & $3>2,4>2,5>2$, \\
\hline & 2.Urta оки & 189 & 350.89 & & & & $5>3,5>4$ \\
\hline & 3.Lise & 233 & 446.28 & & & & \\
\hline & 4.Üniversite & 175 & 425.18 & & & & \\
\hline & 5.Lisans Üstü & 34 & 526.26 & & & & \\
\hline \multirow{5}{*}{ İletişim alt ölçeği } & 1.İlkokul & 173 & 367.69 & \multirow{5}{*}{31.556} & \multirow{5}{*}{4} & \multirow{5}{*}{.00} & $3>1,4>1,5>1$, \\
\hline & 2Orta okul & 189 & 342.58 & & & & $3>2,4>2,5>2$ \\
\hline & 3.Lise & 233 & 451.93 & & & & $5>3$ \\
\hline & 4.Üniversite & 175 & 424.57 & & & & \\
\hline & 5.Lisans Üstü & 34 & 470.74 & & & & \\
\hline
\end{tabular}

Öğrencilerin hem fen öğrenme becerisi ölçeğinin tamamında $\left(\mathrm{x}^{2}(4)=37.50, \mathrm{p}<.05\right)$ hem de ölçeğin bilimsel sorgulama $\left(\mathrm{x}^{2}(4)=38.581, \mathrm{p}<.05\right)$ ve iletişim alt ölçeğinde $\left(\mathrm{x}^{2}(4)=\right.$ 31.556, $\mathrm{p}<.05$ ) anne eğitim düzeyi lehine anlamlı farklılık olduğu belirlenmiştir (Tablo 4). Anne eğitim düzeyi lise ve üzerinde olan öğrencilerin fen becerileri ve alt ölçeklerine (bilimsel sorgulama ve iletişim) ait sonuçlar ile ilkokul ve ortaokul eğitim düzeyine sahip annelerin çocukları arasında fark vardır. 
Ortaokul Öğrencilerinin Fen Öğrenme Becerilerin Baba Eğitim Durumu Açısından İncelenmesi

Ortaokul öğrencilerinin fen becerileri baba eğitim durumuna göre incelendiğinde istatistiksel olarak anlamlı farklar belirlenmiştir. İlgili sonuçlar Tablo 5'te sunulmuştur.

Tablo 5. Ortaokul Öğrencilerinin Fen Öğrenme Becerilerin Baba Eğitim Durumu Açısından Karşılaştırılması

\begin{tabular}{|c|c|c|c|c|c|c|c|}
\hline Ölçekler & $\begin{array}{l}\text { Eğitim } \\
\text { durumu }\end{array}$ & $\mathrm{N}$ & $\begin{array}{c}\text { Sira } \\
\text { ortalamas1 }\end{array}$ & $X^{2}$ & sd & $\mathrm{p}$ & $\begin{array}{l}\text { Anlamlı } \\
\text { farklılık }\end{array}$ \\
\hline \multirow{5}{*}{$\begin{array}{l}\text { Fen Öğrenme } \\
\text { becerisi }\end{array}$} & 1.İlkokul & 116 & 343.42 & \multirow{5}{*}{$\begin{array}{c}39.6 \\
6\end{array}$} & & \multirow{5}{*}{.00} & $3>1,4>1,5>1$ \\
\hline & 2. Orta okul & 166 & 336.87 & & & & $3>2,4>2,5>2$ \\
\hline & 3.Lise & 253 & 416.57 & & 4 & & \\
\hline & 4.Üniversite & 222 & 442.06 & & & & \\
\hline & $\begin{array}{l}\text { 5.Lisans } \\
\text { Üstü }\end{array}$ & 47 & 517.53 & & & & \\
\hline \multirow[t]{4}{*}{$\begin{array}{l}\text { Bilimsel } \\
\text { sorgulama } \\
\text { ölçeği }\end{array}$} & $\begin{array}{l}\text { 1.İlkokul } \\
\text { 2.Orta okul }\end{array}$ & $\begin{array}{l}116 \\
166\end{array}$ & $\begin{array}{l}333.08 \\
339.95\end{array}$ & \multirow{4}{*}{$\begin{array}{c}42.83 \\
2\end{array}$} & \multirow{4}{*}{4} & \multirow{4}{*}{.00} & $\begin{array}{l}3>1,4>1,5>1 \\
3>2,4>2,5>2\end{array}$ \\
\hline & 3.Lise & 253 & 415.59 & & & & \\
\hline & 4.Üniversite & 222 & 444.45 & & & & \\
\hline & $\begin{array}{l}\text { 5.Lisans } \\
\text { Üstü }\end{array}$ & 47 & 520.71 & & & & \\
\hline \multirow{5}{*}{$\begin{array}{l}\text { İletişim } \\
\text { ölçeği }\end{array}$} & 1.İlkokul & 116 & 356.56 & \multirow{5}{*}{\multicolumn{2}{|c|}{$\begin{array}{c}29.30 \\
7\end{array}$}} & \multirow{5}{*}{.00} & \multirow{5}{*}{$\begin{array}{l}3>1,4>1,5>1 \\
3>2,4>2,5>2\end{array}$} \\
\hline & 2.Orta okul & 166 & 342.56 & & & & \\
\hline & 3.Lise & 253 & 418.08 & & & & \\
\hline & 4.Üniversite & 222 & 435.18 & & & & \\
\hline & $\begin{array}{l}\text { 5.Lisans } \\
\text { Üstü }\end{array}$ & 47 & 499.14 & & & & \\
\hline
\end{tabular}


Tablo 5 incelendiğinde öğrencilerin hem fen öğrenme becerisi ölçeğinin tamamında $\left(x^{2}(4)=39.66, p<.05\right)$ hem de bilimsel sorgulama $\left(x^{2}(4)=42.832, p<.05\right)$ ve iletişim alt ölçeklerinde $\left(\mathrm{x}^{2}(4)=29.307, \mathrm{p}<.05\right)$ anlamlı farklılık olduğu belirlenmiştir. Baba eğitim düzeyi lise ve üzerinde olan öğrencilerin fen öğrenme becerisi ölçeği ve alt ölçeklerine (bilimsel sorgulama ve iletişim) ait sonuçlar ile ilkokul ve ortaokul eğitim düzeyindeki babaların çocukları arasında fark vardır.

\section{Ortaokul Öğrencilerinin Fen Becerilerinin Fen Bilimleri Dersi Başarı Notuna Göre İncelenmesi}

Ortaokul öğrencilerinin fen becerileri fen dersi başarı notuna (son öğretim dönemi fen dersi karne notu) göre incelendiğinde farklılık olduğu belirlenmiştir. İlgili sonuçlar Tablo 6'da sunulmuştur.

Tablo 6. Ortaokul Öğrencilerinin Fen Öğrenme Becerilerinin Fen Bilimleri Dersi Başarı Notu Açısından Karşılaştırılması

\begin{tabular}{|c|c|c|c|c|c|c|c|}
\hline Ölçekler & $\begin{array}{c}\text { Fen Başar1 } \\
\text { Notu }\end{array}$ & $\mathrm{N}$ & $\begin{array}{c}\text { Sira } \\
\text { Ortalamas1 }\end{array}$ & $X^{2}$ & $\mathrm{Sd}$ & $\mathrm{p}$ & $\begin{array}{l}\text { Anlamlı } \\
\text { Farklılık }\end{array}$ \\
\hline \multirow{5}{*}{$\begin{array}{l}\text { Fen öğrenme } \\
\text { becerisi }\end{array}$} & 1 & 15 & 237.93 & & & & $5>1$ \\
\hline & 2 & 24 & 231.50 & & & & $4>1$ \\
\hline & 3 & 75 & 312.46 & 64.781 & 4 & .00 & $4>2$ \\
\hline & 4 & 174 & 339.56 & & & & $5>2$ \\
\hline & 5 & 514 & 339.56 & & & & \\
\hline \multirow{6}{*}{$\begin{array}{l}\text { Bilimsel } \\
\text { sorgulama } \\
\text { ölçeği }\end{array}$} & 1 & 15 & 28303 & & & & $5>1$ \\
\hline & & & & & & & $4>1$ \\
\hline & 2 & 24 & 234.03 & & & & $4>2$ \\
\hline & 3 & 75 & 318.63 & 61.194 & 4 & .00 & $5>2$ \\
\hline & 4 & 174 & 334.12 & & & & \\
\hline & 5 & 514 & 447.65 & & & & \\
\hline \multirow{5}{*}{ İletişim alt ölçeği } & 1 & 15 & 242.20 & & & & $5>1$ \\
\hline & 2 & 24 & 243.90 & & & & $4>2$ \\
\hline & 3 & 75 & 311.82 & 54.047 & 4 & .00 & $4>1$ \\
\hline & 4 & 174 & 353.37 & & & & $5>2$ \\
\hline & 5 & 514 & 443.76 & & & & \\
\hline
\end{tabular}


Tablo 6 incelendiğinde hem fen öğrenme becerisi ölçeğinin tamamında $\left(\mathrm{x}^{2}(4)=\right.$ 64.781, $\mathrm{p}<.05)$ hem de bilimsel sorgulama $\left(\mathrm{x}^{2}(4)=61.194, \mathrm{p}<05\right)$ ve iletişim alt ölçeklerinde $\left(\mathrm{x}^{2}(4)=54.047, \mathrm{p}<05\right)$ başarılı öğrenci lehine anlamlı farklılık olduğu belirlenmiştir. Fen başarı notu dört ve üzerinde olan öğrencilerin fen öğrenme becerisi ve alt ölçeklere (bilimsel sorgulama ve iletişim) ait sonuçları, daha düşük başarılı (başarı notu bir veya iki olan) öğrencilerden daha yüksektir.

\section{Ortaokul Öğrencilerinin ASDÖ Açısından Fen Dersinin İşlenişi ile İlgili Görüşleri}

Öğrencilerin ASDÖ açısından fen bilimleri dersinin işleniş biçimi hakkında açık uçlu sorular vasıtasıyla görüşleri alınmıştır. Deney hazırlığı, deney yapma süreci, deney verilerini kaydetme, verilerin analizi, deney öncesi ve sonrası fikirleri karşılaştırma, sonuç paylaşma temaları belirlenmiş ve örnek söylemler Tablo 7'de sunulmuştur.

Tablo.7. ASDÖ Açısından Fen Bilimleri Dersinin Işslenişi Hakkında Öğrenci Görüşlerine Ait Bulgular

\begin{tabular}{|c|c|c|c|}
\hline Tema & Kod & $\mathrm{f}$ & Örnek söylemler \\
\hline \multirow{5}{*}{$\begin{array}{l}\text { Deney } \\
\text { Hazırlığı }\end{array}$} & Soru oluşturma & 12 & Ö1: Deney yapmadan önce verilen bir soru oluyor. \\
\hline & Hipotez kurma & 8 & Ö2: Hipotez oluşturuyoruz ve sorulart \\
\hline & Malzeme & 3 & cevaplandirlyoruz. \\
\hline & hazırlama & 2 & Ö3: Deney öncesinde sorular hazırliyoruz ve \\
\hline & Hazırlık yapmama & & deneyden sonra soruların cevaplarını bulmuş \\
\hline \multirow{2}{*}{$\begin{array}{l}\text { Deney } \\
\text { Yapma }\end{array}$} & Aktif katılım & 10 & Ö6: Herkesin bir rolü var ve aktif olarak \\
\hline & Deneyi izleme & 8 & katıliyorum. \\
\hline \multirow[t]{4}{*}{ Süreci } & Öğretmen yardımı & 5 & Ö3: Bazen katıllyoruz bazen izliyoruz. \\
\hline & Rol almama & 4 & Ö5: Hocamızın evden getirin dediği malzemeleri \\
\hline & İş birliği yapma & 3 & $g \epsilon$ \\
\hline & & & Ö4: Deneyler çok eğlenceli geçiyor, rolüm fikri \\
\hline
\end{tabular}


Deney Not alma

Verilerini

Kaydetme

Grafik ve tablo 10
yapma

Matematiksel ifade
18 Ö3: Daha çok not tutuyorum. Ama deney defterine de tablo çiziyoruz.

Ö1: Konuya göre grafik ve tablo kullanımı değişiyor.

Ö4: Konularımıza göre matematiksel ifadeler kullanıyoruz.

\begin{tabular}{|c|c|c|c|}
\hline \multirow{7}{*}{$\begin{array}{l}\text { Verilerin } \\
\text { Analizi }\end{array}$} & Verileri & 10 & Ö4: Karşılaştırma tekniklerinden yararlanıyoruz. \\
\hline & karşılaştırma & 4 & Ö1: Tablo veya grafik yardımıyla analiz ediyorum. \\
\hline & Not tutma & 2 & Ö2: Bütün verileri topluyorum genel bir sonuca \\
\hline & Tablo veya grafik & & varmak için fikirlerimi paylaşıyorum. \\
\hline & & 2 & Ö3: Sonuçlara varabiliyorum varamadiğım zaman \\
\hline & Fikirleri paylaşma & & araştırlyorum. \\
\hline & Araștırma yapma & & \\
\hline \multirow{6}{*}{$\begin{array}{l}\text { Den } \\
\text { Öncesi ve } \\
\text { Sonrasını } \\
\text { Karşılaştır } \\
\text { ma }\end{array}$} & Evet & 22 & \multirow{6}{*}{$\begin{array}{l}\text { Ö1: Evet. Bazen fikir ve mantık yürüterek doğru } \\
\text { sonuca ulaşıyoruz. } \\
\text { Ö2: Bazen düşüncelerim değişiyor. Ama genelde } \\
\text { tutuyor. } \\
\text { Ö3: Hayır çünkü aklımdakini yapıyorum. }\end{array}$} \\
\hline & & & \\
\hline & Bazen & 9 & \\
\hline & & & \\
\hline & Hayır & 5 & \\
\hline & & & \\
\hline \multirow{7}{*}{$\begin{array}{l}\text { Sonuç } \\
\text { Paylaşma }\end{array}$} & Evet & 18 & \multirow{7}{*}{$\begin{array}{l}\text { Ö3: Evet. Herkesin fikirlerini alarak } \\
\text { karşılaştırıyorum. Genel bir sonuca varmama } \\
\text { yardımcı oluyor. } \\
\text { Ö4: Bazen. Daha çok kendim anlayabilirim. } \\
\text { Anlamadı̆̆ımı ögretmenime sorarım. } \\
\text { Ö5: Evet. Benim görmediklerimi arkadaşlarımdan } \\
\text { görüyorum. }\end{array}$} \\
\hline & Hayır & 6 & \\
\hline & & 4 & \\
\hline & & & \\
\hline & & & \\
\hline & & & \\
\hline & & & \\
\hline
\end{tabular}

Araştırma sonucuna göre öğrenciler deneye başlamadan önce nelerin yapıldığ sorulduğunda genellikle bir soru $(\mathrm{f}=12)$ veya hipotez $(\mathrm{f}=8)$ ile deneye başladıklarını belirtmişlerdir (Tablo 7). Öğrenciler deney yapma aşamasındaki rollerini genellikle süreç 
içerisinde aktif rol alarak ( $\mathrm{f}=10$ ) ve deneyin durumuna göre izleyerek ( $\mathrm{f}=8$ ) de rol aldıklarını belirtmişlerdir. Öğrenciler deney verilerinin kaydedilmesi konusunda daha çok not tutma (f= 18) şeklinde olduğunu ve konuya göre grafik veya tablo ( $\mathrm{f}=10)$ da çizebildiklerini belirtmişleridir. Öğrenciler analiz sonuçlarını daha çok karşılaştırarak yaptıklarını ( $\mathrm{f}=10)$ ifade etmişlerdir. Öğrenciler deney yapmadan önceki fikirleri ile deney yaptıktan sonraki fikirleri hakkında genellikle değişim olduğunu (f=22) belirtmişlerdir. Ayrıca öğrenciler deney sonunda elde ettikleri sonuçları genellikle arkadaşları ile paylaştıklarını ( $\mathrm{f}=18)$ belirtmişlerdir.

\section{Fen Bilimleri Öğretmenlerinin ASDÖ Açısından Fen Dersinin İşlenişi ile İlgili Görüşleri}

Öğretmenlerin ASDÖ açısından fen bilimleri dersinin işleniş biçimi hakkında açık uçlu sorular vasıtasıyla görüşleri alınmıştır. Deney hazırlı̆̆ı, deney yapma süreci, deney verilerini kaydetme, verilerin analizi, analiz sonuçlarını sunma, deney öncesi ve sonrası fikirleri karşılaştırma ve paylaşma temaları belirlenmiş ve örnek söylemler Tablo 8 'de sunulmuştur.

Tablo 8. ASDÖ Açısından Fen Bilimleri Dersinin İşlenişi Hakkında Öğretmen Görüşlerine Ait Bulgular

\begin{tabular}{|c|c|c|c|}
\hline Tema & Kod & $\mathrm{f}$ & Örnek Söylemler \\
\hline \multirow{10}{*}{$\begin{array}{l}\text { Deney } \\
\text { Hazırlığ1 }\end{array}$} & Hipotez & 2 & Öğrt4: Hipotez kurmak gereklidir. Çünkü ögrencinin bilimsel \\
\hline & kurma & & bir gerçekliğe ulaşabilmesi için o konu ile ilgili ne gibi \\
\hline & & & tahmini var ve yapmış olduğu deney sonrasında kurmuş \\
\hline & & & olduğu hipotezle aynı sonuca ulaşıyor mu yoksa değişiklik \\
\hline & Soru & 1 & oluyor mи bunu görebilmesi için hipotez oluşturur. \\
\hline & oluşturma & & Öğrt2: Tabii ki de bir soru ile başlıyoruz çocukların öncelikle \\
\hline & Malzeme & 1 & bir şeylere yani ne üzerine çalışacaklarını bilmeleri için bir \\
\hline & hazırlama & & soru. \\
\hline & & & Öğrt3: Deneye hazırlamak için sinıfa malzemelerle gireriz \\
\hline & & & ögrenci merak eder. \\
\hline \multirow{4}{*}{$\begin{array}{l}\text { Deney } \\
\text { Yapma } \\
\text { Süreci }\end{array}$} & Uygun & 3 & Ö̆̆rt1: Sistemli düzenli olmalarını bekliyoruz. Deneye \\
\hline & deneyi & & başlamadan önce neler yapması gerektiğini planlamasını \\
\hline & planlama & & gerekli olan malzemeleri önceden temin edebilmesini \\
\hline & ve & & sağlıyoruz. \\
\hline
\end{tabular}


hazırlama Ö̆̆rt3: Ardından kullanacaklarl malzemeleri belirlemeleri uygun malzemelerle uygun deney düzeneklerini hazırlamaları gerekir.

\begin{tabular}{|c|c|c|c|}
\hline $\begin{array}{l}\text { Deney } \\
\text { Verilerini }\end{array}$ & Not tutma & 2 & $\begin{array}{l}\text { Öğret3: Genellikle deney yapmaya ilgi duyan ögrenciler veri } \\
\text { toplama sürecinde not almayı tercih ediyorlar }\end{array}$ \\
\hline Kaydetme & $\begin{array}{l}\text { Grafik ve } \\
\text { tablo } \\
\text { yapma }\end{array}$ & 2 & $\begin{array}{l}\text { Öğrt2: Zamana bağlı olarak bir şeyleri ölçüyorsa bunları } \\
\text { tablo şeklinde kaydetmelerini artış ya da azalış gibi değişken } \\
\text { ifadeler varsa bunlarl grafikle göstermelerini istiyoruz. }\end{array}$ \\
\hline $\begin{array}{l}\text { Verilerin } \\
\text { Analizi }\end{array}$ & $\begin{array}{l}\text { Tablo/grafi } \\
\text { k ile analiz } \\
\text { yapma } \\
\text { Analiz } \\
\text { yapamama }\end{array}$ & 1 & $\begin{array}{l}\text { Öğrtl: Bir süratle ilgili deney yaptığımız zaman analiz } \\
\text { sonuçlarını zaten grafik üzerinden değerlendirmek } \\
\text { zorundalar. Isı sıcaklıkla ilgili deney yapıldığında mutlaka } \\
\text { gene grafikler kullanılır. } \\
\text { Öğrt2: Deney salonumuz yok sınıfta yaptı̆̆ımız için analiz } \\
\text { yapamıyorlar. Sadece gösteri deneyleri oluyor bizim okulda } \\
\text { yaptıklarımız. Öğrenci tabi deneyi yaptıktan sonra kendi } \\
\text { düşüncesinden ziyade deneyde ne anladı ise onu söylüyor. }\end{array}$ \\
\hline
\end{tabular}

Analiz $\quad$ Çizim, $\quad 3$ Öğrt3: Tek bir bakış açısına bağlı kalmayıp onu hem sayısal

Sonuçlarını grafik, olarak ifade etme hem sözel olarak ifade etme ya da saylsalı

Sunma sözel ifade sözele ya da sözeli saylsala grafiğe dönüştürme şeklinde de kullanma olabilir.

\section{Deney}

Öncesi ve Karşılaştır

Sonrasinı ma yapma

Karşılaştır

ma
4 Öğrt2: Deney yaptıklarında ikna olmuş oluyorlar. Kendi sonuçlarından farklı sonuçlar bulmuş olurlarsa elbette tepki gösterdikleri oluyor. Çünkü her grup kendi sonuçlarının doğru olduğuna inanmak istiyor. Bu inançla birlikte birbirlerini yargılayabiliyorlar, yanlış bulduklarl yerlerde düzeltmek isteyebiliyorlar.

Öğrt4: Kendi argümanlarını ya da diğer arkadaşlarının argümanlarını analiz ederken yargılama düşüncesi eksik kalıyor biraz açıkçası.

\begin{tabular}{ccclcc}
\hline Paylaşma & Grup & 1 & Öğrtl: Grup sözcüsüyle birlikte grup üyeleri yapıyor \\
& sözcüsü & & paylaşımı bireysel deneylerde fikri söylemek isteyenlerin \\
& seçme & & fikirleri alınabiliyor. Bazen de birbirlerinin deneylerini
\end{tabular}


gruplar yer değiştirerek sonuçlarını gözlemlemek amaçlı

Öğrenci- $\quad 2$ istasyon yöntemini kullanarak sonuçlarını paylaşabiliyorlar

Öğrenci

Ö̆̆rt2: Elde ettikleri verileri arkadaşları ile paylaşlyorlar.

etkileşimi

Farklı alanda deney yaptıkları zaman gruplar arasında farklı

sonuçlar var mı aynı sonuçlara $m \imath$ ulaşıllyor bunları karşılaştırma ya da destekleme imkanı bulmuş oluyorlar.

Öğretmenlerle yapılan mülakatlar sonrasında, öğrencilerin ders içerisinde uygulanan bir etkinlik ya da deneye başlamadan önce genel olarak bir hipotez ( $\mathrm{f}=2$ ) veya soru $(\mathrm{f}=1)$ ile derse başlamanın gerekli olduğunu düşündüklerini ve bu konuda öğrencileri yönlendirdikleri tespit edilmiştir (Tablo 8). Öğrencilerin veri toplama sürecine aktif olarak katılımlarını sağlamak için not tutma ( $\mathrm{f}=2$ ), grafik çizme veya tablo $(\mathrm{f}=2)$ oluşturmalarını istediklerini belirtmişlerdir. Ayrıca verilerin analizinde grafik kullanımını $(\mathrm{f}=2)$ tercih eden öğretmenler olduğu gibi öğrencilerin deneylerin laboratuvar ortamında gerçekleştirilmemesinden dolayı deney sonrasında analiz yapamadıklarını belirten öğretmen $(\mathrm{f}=1)$ olduğu da belirlenmiştir. Analiz sonuçlarının sunumunda ise çizim, grafik, sözel ifade kullanımın ( $\mathrm{f}=3$ ) tercih edildiği belirlenmiştir. Öğrencilerin deney yapmadan önce ve deney yaptıktan sonraki düşüncelerini karşılaştırdığında, grup çalışmalarında birçoğunun süreç sonucunda kendi bulduğu sonuçlar ile karşı grubun bulduğu sonuçları kıyasladıklarını ( $\mathrm{f}=4$ ) ifade etmişlerdir. Zaman zaman karşı grubun sonuçlarını eleştirdiklerini ya da aralarında rekabet oluşabildiğini belirtmişlerdir. Öğretmenler öğrencilerin deney sonucunu arkadaşları ile paylaşımını bazen grup sözcüsü $(f=1)$ seçilerek bazen de diğer gruplar ile yer değiştirerek $(f=2)$ sonuçları gözlemledikleri, tartışmalarla öğrencilerin birbirleriyle iletişim kurduklarını belirtilmiştir.

\section{Sonuç ve Tartışma}

$\mathrm{Bu}$ araştırmada, farklı sınıf düzeylerindeki ortaokul öğrencilerinin fen öğrenme becerileri çeşitli değişkenlere göre incelenmiştir. Çünkü sorgulamaya dayalı öğretim öğrencilerin hem bilim anlayışını hem de bilime karşı ilgilerini arttırarak bilimsel okur yazarlıklarını geliştirme potansiyeline sahip bir öğretim yöntemidir (Capps, \& Crawford, 2013). Pek çok ülkede olduğu gibi ülkemizde de bu öğretim stratejisinin kullanımı önerilmiş (MEB, 2005, 2008, 2013; NRC, 1996, 2000; Tytler, \& Hobbs, 2011) ve etkilerinin incelenmesi değerli görülmüştür. Buna göre sonuçlar araştırmaya katılan ortaokul öğrencilerinin fen öğrenme beceri düzeylerinin ortalamanın üzerinde olduğunu göstermiştir. Öğrencilerin, fen öğrenme becerisi ölçeğinin alt ölçekleri olan bilimsel sorgulama ve iletişim yeterliklerinin de ortalamanın üzerinde olduğu belirlenmiştir. Araştırmanın nitel boyutunda hem öğrenciler 
hem de öğretmenler ASDÖ açısından fen derslerinin işlenişi ile ilgili görüşleri nicel sonuçları desteklediği ve fen derslerinde ASDÖ ortamının sağlandığını göstermektedir. Öğretmenler, derslerinde öğrencileri sorgulamaya sevk ettiklerini, gerektiğinde öğrencilere yönlendirme yaptıklarını belirtmişlerdir. Deney yapma sürecinde ne tür adımlar izlemeleri gerektiği konusunda öğrencilere rehberlik yaptıklarını, süreç sonunda bilimsel bir sonuca ulaşıldığında nasıl analiz etmeleri gerektiğini ve analiz sonuçlarını nasıl değerlendirmeleri gerektiği konusunda yardımcı olduklarını ifade etmişlerdir. Duran (2015), araştırmasında hazırlanmış rehber etkinlikler ile desteklenen fen ve teknoloji derslerinin, öğrencilerin sorgulayıcı öğrenme becerileri üzerinde anlamlı bir etkisi olmadığını belirtmiştir. Sorgulama sürecinde öğretmenin öğrencilere rehberlik yapması ile öğrencilerin, onlara hazır olarak verilen rehber etkinlikleri uygulamalarının sonuçları kıyaslandığında sorgulama becerilerini farklı olarak etkilediği yorumu yapılabilmektedir. Ancak bu araştırmada öğretmenlerin öğrencilere sorgulama sürecinde rehberlik yapmalarının olumlu sonuçlar doğurduğu düşünülmektedir. Bundan dolayı öğretmenlerin öğrencileri sorgulama sürecine yönlendirmeleri ve aynı zamanda onlara gerektiği durumlarda rehber olmaları gerekmektedir (Dobbler, Zward, Tanis, \& Oers, 2017). Öğrenciler ise araştırma sorgulama sürecinde genellikle aktif olduklarını, bilimsel bir sonuca ulaştıklarında deney yapmadan önceki düşüncelerle deney yaptıktan sonraki düşüncelerinin değişebildiğini belirtmişlerdir. Öğrencilerin sürece araştırma sorusu veya hipotez hazırlama, deney yapma, veri toplama, analiz etme ve bunu diğer arkadaşları ile paylaşma aşamalarını gerçekleştirdiklerini belirtmeleri araştırma sorgulamaya dayalı bir öğrenme ortamı yaşadıklarının bir göstergesidir. Bu durum araştırmanın nicel boyutunda fen öğrenme becerilerinin ortalamanın üzerinde olmasının nedenini bir ölçüde açıklamaktadır.

ASDÖ ile kız ve erkek öğrencilere müfredat kapsamında kendi fikirlerini keşfetme ve destekleme firsatı sunulur (Wolf \& Fraser, 2008). Ancak bu araştırmada kız öğrencilerin fen öğrenme becerileri ile erkek öğrencilerin fen öğrenme becerileri karşılaştırıldığında kızlar sonuçların lehine olduğu ve bunun Aslan-Efe ve Özmen (2018)'ün araştırma sonuçlarına paralel olarak olduğu gözlenmiştir. Buna karşın Wolf ve Fraser’’n, (2008) sorgulamaya dayalı laboratuvar etkinliklerinin kız ve erkek öğrenciler için farklı şekilde etkili olduğu görülmüştür. Erkeklerin sorgulamaya dayalı yöntemin etkilerinden daha çok yararlandığ1, buna karşın kızların özellikle fene yönelik tutum, sınıf içi görev paylaşımı, iş birliği ve eşitliği gibi konularında sorgulamaya dayalı olmayan yaklaşım uygulamalarından daha çok yararlandıkları belirlenmiştir. Cinsiyete göre farkın nedenleri, bu araştırmada sorgulanmasa 
da benzer sonuçların varlığı ya da olası nedenlerin araştırılması değerli bir konudur ve araştırmacıların bu konuya yönelmeleri önerilmektedir.

Fen beceri ölçeğinin alt ölçekleri ayrı ayrı incelendiğinde öğrencilerin bilimsel sorgulama alt ölçeğinden ve iletişim alt ölçeğinden aldıkları puanların kız öğrencilerin lehine olduğu belirlenmiştir. Bilimsel sorgulama alt ölçeğinin boyutları incelendiğinde deney yapma ve veri toplama temasında kız öğrencilerin ortalamalarının erkek öğrencilerin ortalamalarından yüksek olduğu gözlenmiştir. Araştırmanın bu bulguları Şenler (2014) ve Aslan-Efe ve Özmen (2018) çalışmaları ile benzerlik göstermektedir. Buna karşın Duran (2014) 7. sınıf öğrencilerinin cinsiyetlerine göre iletişim ve sorgulama becerileri açısından bir farklılığın olmadığını sorgulama becerilerinin iletişim becerilerine paralel olarak arttığını ifade etmiştir. Araştırmalar arasındaki cinsiyet değişkenine bağlı araştırma sonuçlarında yaşanan bu farklılıkların tekrar değerlendirilmesi önerilmektedir.

Sorgulamaya dayalı öğrenme, iş birliğine dayalı bir öğrenmedir ve bu öğrenmede, erkek ve kız öğrenciler, çözülmesi gereken bir problemi çözmek için eğitim sürecinde iş birliği yaptıkları aynı grupta toplanırlar (Nunaki, Damopolii, Kandowangko, \& Nusantari, 2019). Bunun nedeni öğretmenlerin ekonomik nedenlerle genellikle öğrencileri grupla deney yapmaya yönlendirmesi ve iş birliği içinde geçen bu süreçte daha çok iletişim kurmaları ve öğrencilerin kendilerini daha fazla ifade etme firsatı bulmalarını sağlamaktır (Raviv, Cohen, \& Aflalo, 2019). Aydın (2016) sorgulamaya dayalı uygulamaların iddiaları değerlendirmeyi, fikirleri araştırmayı, problemleri çözmeyi, geçerli sonuçlar çıkarmayı ve kanıta dayalı argümanlar geliştirmeyi gerektirdiğinden öğrencilerin iletişim becerilerini etkilediğini, onları hem sosyal hayata hem de profesyonel kariyere hazırladığını belirtmiştir. Bu araştırmada iletişim alt ölçeğinde yer alan alt boyutların cinsiyet değişkenine göre incelendiğinde etkileşimde bulunma ve müzakare etme boyutlarında yine kız öğrencilerin lehine anlamlı olduğu belirlenmiştir. $\mathrm{Bu}$ sonuçlardan yola çıkarak sınıf içerisinde yapılan fen etkinliklerinde bilimsel sorgulama adına deney yapma ve veri toplama ve bu etkinlikler esnasında iletişim açısından etkileşimde bulunma ve müzakere etme sürecine katılımda kız öğrencilerin beceri düzeylerinin erkek öğrencilerden daha yüksek olduğu söylenebilir. Duran (2014), araştırmasında ise cinsiyete yönelik bir farklılık gözlenmezken, öğrencilerin iletişim becerisi alt boyutlarından olan kendini ifade etme becerisine sahip olduklarını ancak soru sorma becerisinde yeterli bulmadıklarını belirlemiştir. Araştırmanın nitel boyutunda daha önce de belirtildiği gibi cinsiyete bağlı bir değerlendirme yapılmamasına karşın, deney sırasında aktif rol alma, analiz sonuçlarını karşılaştırma, arkadaşlarıyla paylaşma süreçleri 
konusundaki söylemler ASDÖ ortamında yeterli iletişimin olmasının önemini yansıtmaktadır. Öğretmenlerin bu süreçte iletişime yönelik kullandıkları teknikler de önemlidir. Çünkü araştırmaya katılan öğrencilerin iletişim alt ölçeği puanları ortalamanın üstündedir.

Ortaokul öğrencilerinin fen becerileri anne ve baba eğitim durumuna göre incelendiğinde hem fen öğrenme becerisi ölçeğinin tamamında hem de bilimsel sorgulama ve iletişim alt ölçeklerinde anlamlı farklılık olduğu belirlenmiştir. Anne ve babalarının eğitim düzeyi lise ve üzeri olan öğrencilerin fen öğrenme becerilerinin daha yüksek olabileceği söylenebilir. Aslan-Efe ve Özmen (2018) de öğrencilerin fen öğrenme becerilerinin ebeveynlerin eğitim durumlarıyla ilişkili bulmuş ve ebeveynleri üniversite mezunu olanların, yine ebeveynleri ilkokul ve ortaokul mezunu olan öğrencilerden yüksek olduğunu belirtmiştir. Eğitim düzeyi yüksek olan ebeveynlerin eğitim açısından destekleyici bir tutum sergilemeleri düşünüldüğünde (Özer \& Anıl, 2011) bu durumun çocukların başarılarına olumlu yansıdığı söylenebilir. Öyle ki MEB'in 2020 Ortaöğretim Kurumlarına İlişkin Merkezi Sınav raporu da anne ve babanın eğitim düzeyindeki artışın öğrencilerin sınav puanlarına olumlu yansıdığını göstermiştir (MEB, 2020).

Araştırmanın önemli bulgularından biri de fen başarısı yüksek olan öğrencinin fen öğrenme becerisi, bilimsel sorgulama ve iletişim yeterliklerinin yüksek olmasıdır. Fen başarı notu dört ve üzerinde olan öğrencilerin fen öğrenme becerileri ve alt ölçeklerine ait sonuçlar daha düşük başarıya sahip öğrencilerden yüksektir. Varlı ve Uluçınar Sağır (2019) da ASDÖ'nün öğrencilerin akademik başarıları, fenı öğrenme becerileri ve üst bilişleri üzerine olumlu etkileri olduğunu belirtmiştir. Sarı ve Şaşmaz Ören (2020) ise öğrencilerin akademik başarısına olan olumlu yönde etkisinin diğer öğretim yöntemlerine göre daha etkili olduğu sonucuna varmıştır. Ancak bu sonuçlardan ASDÖ’nun diğer öğretim yöntemlerinden daha iyi olduğu yargısına varılmamalıdır. Nitekim Gülhan ve Yurdatapan (2014) ASDÖ’nün uygulandığı ortaokul 5. sınıf öğrencilerinin çevreyle ilgili tutum ve davranışlarında deney grubu ve kontrol grubu arasında anlamlı bir fark olmadığını tespit etmiştir. Ayrıca Cairns ve Areepattamannil, (2019) pek çok ülkeye ait verileri içeren kapsamlı çalışmasında öğrenci, okul ve ülke düzeyindeki demografik özellikleri ve öğrencilerin fene yönelik eğilimlerinin, artan ASDÖ sıklığı ile fen başarısı arasında olumsuz bir ilişki ortaya koymuştur. Bu olumsuzluğun nedeni öğrencilerin deneyimlediği araştırma sorgulamaya dayalı öğretimin kalitesiyle ilişkili olabilir (Cairns \& Areepattamannil, 2019). Çünkü araştırmacılar araştırma sorgulamaya dayalı öğretimin fen öğrenmeye karşı ilgi ve zevk alma, bilimle ilgili geleceğe 
yönelik motivasyon, benlik kavramı ve öz-yeterlik gibi bilime yönelik eğilimlerle önemli ölçüde olumlu ilişkisi olduğunu ifade etmişlerdir (Cairns \& Areepattamannil, 2019).

Öğrencilerin fen öğrenme becerilerinin sınıf düzeyi açısından karşılaştırılması sonucunda öğrencilerin fen becerileri arasında anlamlı fark olmadığı 8. sınıf ile 5. sınıf öğrencileri arasında ve 7. sınıf ile 5. sınıf öğrencileri arasında sınıf düzeyi lehine anlamlı fark tespit edilmiştir. Bu sonuçlar öğrencilerin sınıf düzeyine göre bilimsel sorgulama yeterliklerinin farklılık göstererek sınıf düzeyi arttıkça bilimsel sorgulama yeterliklerinin arttığını göstermektedir. Benzer sonuçlar öğretmen adaylarıyla çalışan Celep Havuz ve Karamustafaoğlu'nun (2016) araştırmasında da ortaya çıkmış, ASDÖ algısının üst sınıflar lehine anlamlı olduğu sonucuna ulaşmışlardır. Sınıf düzeyi arttıkça öğrencilerin fen öğrenme becerisinin artması her sınıf düzeyinde biriktirdikleri bilgi ve deneyimlerinden kaynaklandığı söylenebilir.

\section{Öneriler}

Araştırmada öğrencilerinin fen öğrenme beceri düzeylerinin her alt ölçekte ortalama puanın üzerinde olduğu belirlenmiş ancak cinsiyet açısından kızlar lehine anlamlı farklılık belirlenmiştir. $\mathrm{Bu}$ farklılı̆̆ın sebeplerinin araştırılması, öğretmen rolünün etkisi ya da motivasyon, öz düzenleme becerisi gibi faktörlerin etkisinin incelenmesi önerilmektedir. Ayrıca araştırmada ebeveyn eğitim düzeyi ile öğrencinin fen öğrenme becerisinin ilişkili olduğu sonucuna ulaşılmıştır. Ebeveyn eğitim düzeyinin farklı yaş gruplarında (ortaöğretim ve üniversite) ya da üstün yetenekli öğrenciler gibi bilişsel farklılıkları olan gruplarda benzerlik durumunun araştırılması, fen derslerinde ASDÖ yapılması konusunda oluşturulan eğitim politikasının gözden geçirilmesine firsat oluşturacağı düşünülmektedir.

Fen başarısı yüksek olan öğrencinin fen öğrenme becerisi, bilimsel sorgulama ve iletişim yeterliklerinin yüksek olduğu, buna karşın sınıf düzeyi arttıkça fen öğrenme becerisinin düştüğü belirlenmiştir. Ancak fen öğrenme becerisi ve iletişim konusunda yapılan çalışmaların sınırlı olması nedeniyle bu konuda çalışan araştırmacılara ilkokul, ortaöğretim ve üniversite grubundan üzerine odaklanmaları önerilmektedir. Bununla birlikte araştırmada öğretmenlerin mesleki tecrübeleri açısından bu konu hakkındaki görüşlerinin farklılaşma durumu değerlendirilmemiştir. Benzer bir araştırma yürütecek araştırmacılara bu değişkeni de göz önünde bulundurmaları önerilmektedir.

Araştırma sonuçlarında; erkek öğrencilerin, ebeveyn eğitim düzeyi düşük olan öğrencilerin, fen başarısı düşük öğrencilerin ve üst sınıf düzeyindeki öğrencilerin fen 
öğrenme becerilerinin düşük olduğu belirlenmiş ancak söz konusu farkl1lıkların nedenleri araştırılmamıştır. Bu nedenle araştırmacılara bu konulara odaklanmaları, ayrıca fen öğrenme becerisi düşük olan grupların desteklenmesi gerektiği fen öğretmenlerine önerilmektedir. Ancak Açıkgöz ve Uluçınar Sağır (2019) fen öğretmenlerinin araştırma sorgulamaya dayalı öğretime yönelik farkındalıklarını belirlemeye yönelik yaptıkları araştırmada öğretmenlerin ASDÖ konusunda net bir bilgiye sahip olmadıkları ve az sayıda öğretmenin araştırma sorgulamaya dayalı öğretim yaklaşımını sınıflarında uygulamaya çalıştıklarını belirlemiştir. Araştırma bulguları da öğretmenlerin sınıflarında araştırma sorgulama sürecini gerçekleştirmeye çalıştığını göstermektedir. Ancak öğretmenlere, öğrencilerin fen öğrenme becerilerini geliştirmek adına öğrenme ortamında özellikle ASDÖ’nün bilimsel sorgulama ve iletişim alt boyutlarına daha fazla vurgu yapmaları, soruları ile öğrencileri yönlendirmeleri, onlara kendilerini ifade edebilme firsatları sunmaları, öğrencilerin topladıkları verilerden yola çıkarak iddia ve delil oluşturmaları ve bunları arkadaşları ile tartışacakları ve müzakere edebilecekleri ortamlar oluşturmaları önerilmektedir.

Etik Kurul İzin Bilgisi: Bu araştırma birinci yazarın yüksek lisans tezinden üretilmiş olup, Milli Eğitim Bakanlığının 12/05/2017 tarih ve 29409993-605.01-E.6862726 sayılı izini ile yürütülmüştür

Yazar Çıkar Çatışması Bilgisi: Bu çalışmada çıkar çatışması yoktur ve finansman desteği alınmamıştır

Yazar Katkısı: Yazar katkısı eşittir.

\section{Kaynakça}

Abd-El-Khalick, F., Boujaoude, S., Duschl, R., Lederman, N. G., Mamlok-Naaman, R., Hofstein, A. \& Tuan, H. L. (2004). Inquiry in science education: International perspectives. Science Education, 88(3), pp.9-13. https://doi.org/10.1002/sce.10118

Açıkgöz, D. \& Uluçınar Sağır, Ş. (2019). Fen alanı öğretmenlerin araştırma sorgulamaya dayalı öğretime yönelik tutumlarının incelenmesi. Electronic Journal of Education Sciences, 8(16), 172-187. https://dergipark.org.tr/tr/pub/ejedus/issue/51353/630948

Alemli, A. (2019). Fen eğitiminde araştırma sorgulama temelli öğrenme yaklaşımının etkililiğinin meta analiz yöntemiyle incelenmesi. Yayımlanmamış yüksek lisans tezi, Kastamonu Üniversitesi, Sosyal Bilimler Enstitüsü. 
Antink-Meyer, A., Bartos, S., Lederman, J. S., \& Lederman, N. G. (2016). Using science camps to develop understandings about scientific inquiry-Taiwanese students in U.S. summer science camp. International Journal of Science and Mathematics Education, 14(1), 29-53.

Aslan-Efe, H. \& Özmen, S. (2018). Ortaokul öğrencilerinin fen öğrenme becerilerinin incelenmesi. Journal of Computer and Education Research, 6(11), 88-105. https://doi.org/10.18009/jcer.376953

Aydın, G. (2016). Reflections of inquiry-based laboratory experiments on prospective teachers' communication skills. International Online Journal of Educational Sciences, 8(2), 49-61. http://dx.doi.org/10.15345/iojes.2016.02.005

Baki, A., \& Gökçek, T. (2012). Karma yöntem araştırmalarına genel bir bakış. Elektronik Sosyal Bilimler Dergisi, $\quad 11(42), \quad$ 1-21. https://dergipark.org.tr/tr/pub/esosder/issue/6156/82721

Bilir, U. \& Özkan, M. (2018). Fen bilimleri öğretiminde araştırma ve sorgulamaya dayalı öğrenme yaklaşımının öğrencilerin akademik başarısına etkisi. Uludă̆ Üniversitesi Ĕ̈itim Fakültesi Dergisi, 31(1), 223-256. https://doi.org/10.19171/uefad.450103

Bybee, R. (2000). Teaching science as inquiry. In J. Minstrell, \& E. van Zee (Eds.), Inquiring into inquiry learning and teaching in science (pp. 20-46). Washington, DC: American Association for the Advancement of Science.

Cairns, D., \& Areepattamannil, S. (2019). Exploring the relations of inquiry-based teaching to science achievement and dispositions in 54 countries. Research in Science Education, 49(1), 1-23. https://doi.org/10.1007/s11165-017-9639-x

Capps, D. K., \& Crawford, B. A. (2013) Inquiry-based instruction and teaching about nature of science: are they happening? Journal of Science Teacher Education, 24(3), 497526. https://doi.org/10.1007/s10972-012-9314-z

Celep Havuz, A. \& Karamustafaoğlu, S. (2016). Fen bilgisi öğretmen adaylarının araştırma sorgulamaya dayalı öğrenme algılarının incelenmesi. Amasya Üniversitesi Ĕ̈itim Fakültesi Dergisi, 5(1), 233-247.

Chang, H. P., Chen, C. C., Guo, G. J., Cheng, Y. J., Lin, C. Y., \& Jen, T. H. (2011). The development of a competence scale for learning science: Inquiry and communication. International Journal of Science and Mathematics Education, 9(5), 1213-1233. 
Creswell, J. W., \& Plano Clark, V. L. (2014). Karma yöntem araştırmaları, tasarım ve yürütülmesi. (2. Baskıdan çeviri). (Çev. Ed.: Y. Dede ve S. B. Demir). Ankara: Anı.

Dobbler, M., Zward, R. C., Tanis, M., \& Oers, B. (2017). Literature review: The role of the teacher in inquiry-based education. Educational Research Review, 22, 194-214.

Doğan, N., Han-Tosunoglu, Ç., Özer, F. \& Akkan, B. (2020). Ortaokul öğrencilerinin bilimsel sorgulama görüşleri: cinsiyet, sınıf düzeyi ve okul türü değişkenlerinin incelenmesi. Pamukkale Üniversitesi Eğitim Fakültesi Dergisi, 49, 162-189. https://doi.org/10.9779/pauefd.515080

Duban, N. (2008). Illköğretim fen ve teknoloji dersinin sorgulamaya dayalı öğrenme yaklaşımına göre işlenmesi: Bir eylem araştırması. Yayınlanmamış doktora tezi, Anadolu Üniversitesi, Eskişehir.

Duran, M. (2014). Study on 7th grade student's inquiry and communication competencies. Procedia Social and Behavioral Sciences, 116, 4511-4516

Duran, M. (2015). Araştırmaya dayalı öğrenme yaklaşımına dayalı etkinliklerin öğrencilerin sorgulayıcı öğrenme becerileri üzerine etkisi, The Journal of Academic Social Science Studies, 32, 399-420.

Duran, M. \& Dökme, İ. (2018). Araştırmaya dayalı öğrenme yaklaşımının kavramsal anlama düzeyi ve bazı öğrenme çıktıları üzerine etkisi. Trakya Ĕ̆itim Dergisi, 8(3), 559577.

Gülhan, F. \& Yurdatapan, M. (2014). Araştırma sorgulamaya dayalı etkinliklerin çevre ile ilgili tutum ve davranışlara etkisi. Mustafa Kemal Üniversitesi Sosyal Bilimler Enstitüsü Dergisi, 11 (27), 237-258

Johnson, R. B., Onwuegbuzie, A., \& Turner, L. (2007). Toward a definition of mixed methods research. Journal of Mixed Methods Research, 1(2), 122-133.

Keçeci, G. (2014). Araştırma ve sorgulamaya dayalı fen ögretiminin öğrencilerin bilimsel süreç becerilerine ve tutumlarına etkisi. Yayımlanmamış doktora tezi, Fırat Üniversitesi, Eğitim Bilimleri Enstitüsü.

Kızılaslan, A., Sözbilir, M., \& Yaşar, M. D. (2012). Inquiry based teaching in Turkey: A content analysis of research reports, International Journal of Environmental \& Science, 7(4), 599-617. 
Milli Eğitim Bakanlığı [MEB], (2005, 2013, 2018). Fen Bilimleri Dersi Öğretim Programı (Ilkokullar ve Ortaokullar 3, 4, 5, 6, 7 ve 8. Sinıflar). Ankara: Talim ve Terbiye Kurulu.

Milli Eğitim Bakanlığı [MEB], (Temmuz 2020). 2020 Ortaöğretim Kurumlarına İlişkin Merkezi Sınav Raporu, Eğitim Analiz ve Değerlendirme Raporları Serisi No:13, Ankara: MEB Yayınları.

National Research Council [NRC] (1996). National science education standards. Washington, DC: National Academy Press.

National Research Council [NRC] (2000). Inquiry and the national science education standards. Washington: National Academy Press.

Next Generation Science Standards [NGSS], (2013). Next Generation Science Standards: For states, by states. Washington, DC: National Academies Press. www.nextgenscience.org/next-generation-science-standards

Nunaki, J. H., Damopolii, I., Kandowangko, N. Y., \& Nusantari, E. (2019). The effectiveness of inquiry-based learning to train the students' metacognitive skills based on gender differences. International Journal of Instruction, 12(2), 505-516. https://doi.org/10.29333/iji.2019.12232a

Organization for Economic Cooperation and Development (2005). The definition and selection of key competencies: Executive summary. Paris, France.

Özer, Y., ve Anıl, D. (2011). Öğrencilerin fen ve matematik başarılarını etkileyen faktörlerin yapısal eşitlik modeli ile incelenmesi. Hacettepe Üniversitesi Eğitim Fakültesi Dergisi, 41, 313-324.

Perry, V. R., \& Richardson, C. P. (2001). "The New Mexico Tech Master of Science teaching program: an exemplary model of inquiry-based learning," 31st Annual Frontiers in Education Conference. Impact on Engineering and Science Education. Conference Proceedings (Cat. No.01CH37193), Reno, NV, USA, 2001, pp. T3E-1, doi: 10.1109/FIE.2001.963917.

Raviv, A., Cohen, S., \& Aflalo, E. (2019). How should students learn in the school science laboratory? the benefits of cooperative learning. Research in Science Education, 49(2), 331-345. https://doi.org/10.1007/s11165-017-9618-2 
Sarı, K. \& Şaşmaz Ören, F. (2020). Araştırmaya dayalı öğrenme stratejisinin öğrencilerin akademik başarılarına etkisi: bir meta analiz çalışması. Hacettepe Üniversitesi Eğitim Fakültesi Dergisi, 35(3), 540-555.

Schwartz, R. S. (2004). Epistemological views in authentic science practices: A cross discipline comparison of scientists' views of nature of science and scientific inquiry. Unpublished doctoral dissertation, Oregon State University, Corvallis, Oregon.

Şenler, B. (2014). Fen öğrenme becerisi ölçeğinin Türkçe’ye uyarlaması: geçerlik ve güvenirlik çalışması. Eğitimde Kuram ve Uygulama, 10 (2), 393-407.

Taş, E., Başoğlu, S., Sarıgöl, J., Tepe, B. \& Güler, H. (2019). Türkiye'de 2008-2018 yılları arasında araştırma ve sorgulamaya dayalı öğrenme yaklaşımına ilişkin fen eğitimi alanında yapılan bilimsel çalışmaların incelenmesi. Ordu Üniversitesi Sosyal Bilimler Araştırmaları Dergisi, 9(1), 69-78.

The National Curriculum in England (2013). Key stages 1 and 2 framework document 31.08.2020 tarihinde https://assets.publishing.service.gov.uk/government/uploads/system/uploads/attachm ent_data/file/425601/PRIMARY_national_curriculum.pdf adresinden alınmıştır.

Timur, B. \& Kıncal, R. Y. (2010). İlköğretim 7. sınıf fen bilgisi dersinde sorgulamalı öğretimin (inquiry teaching) öğrenci başarısına etkisi. Türk Eğitim Bilimleri Dergisi, $8(1), 4165$.

Tytler, R., \& Hobbs, L. (2011), The Australian science curriculum, Primary and middle years educator, $9(2), 3-10$.

Varlı, B. \& Uluçınar Sağır, Ş. (2019). Araştırma sorgulamaya dayalı öğretimin ortaokul öğrencilerinin fen başarısı, sorgulama algısı ve üstbiliş farkındalığına etkisi. Gazi Üniversitesi Eğitim Fakültesi Dergisi, 39(2), 703-725.

Wildan, W., Hakim, A., Siahaan, J., \& Anwar, Y. A. S. (2019). A stepwise inquiry approach to improving communication skills and scientific attitudes on a biochemistry course. International Journal of Instruction, 12(4), 407-422. https://doi.org/10.29333/iji.2019.12427a

Wolf, S. J., \& Fraser, B. J. (2008). Learning environment, attitudes and achievement among middle-school science students using inquiry-based laboratory activities. Research in Science Education, 38, 321-341. https://doi.org/10.1007/s11165-007-9052-y 
Wu, H. K., \& Krajcik J. S. (2006). Inscriptional practices in two inquiry-based classrooms: A case study of seventh graders' use of data tables and graphs. Journal of Research in Science Teaching, 43(1), 63-95.

Yıldırım, A. \& Şimşek, H. (2018). Sosyal bilimlerde nitel araştırma yöntemleri. 11. Baskl. Ankara: Seçkin. 


\title{
Investigation of Competence for Science Learning of Middle School Students
}

\section{According to Various Variables*}

\author{
Gülcan Özdemir**, Seda Çavuş Güngören ${ }^{* * *}$, Funda Yeşildağ-Hasançebi ${ }^{* * * * *}$
}

- Received: 23.09.2020 • Accepted: 31.05.2021 • Online First: 07.06.2021

\begin{abstract}
The aim of this study is to investigate how competence for science learning(CSL) of middle school students at different grade levels change according to various variables. In addition, the study aims to reveal the views of students and science teachers about the teaching of science courses in terms of Inquiry-Based Learning (IBL). The study was conducted with exploratory sequential mixed methods. A total of 805 students at different grade levels and 4 science teachers participated.CSL scale that was developed by Chang et all(2011) and adopted in Turkish by Şenler(2014), open-ended questions, and semi-structured interviews were used as data collection tools. Mann-Whitney U Test and Kruskal Wallis, which are nonparametric tests, were used in the analysis. The open-ended questions and semi-structured interviews were analyzed with content analysis. Results showed that CSL scale scores of the students were above average; the difference according to gender was in favor of female students; parent education level was related to CSL; students' CSL, scientific-inquiry and communication competencies with high science achievement were high; it was found that as the grade level increased, scientific-inquiry competencies decreased. It was determined that the views of teachers and students about the teaching of the science course in terms of IBL were parallel to the results of both each other and the quantitative data.
\end{abstract}

Keywords: competence for science learning, scientific inquiry competence, communication competence, science achievement, parent education level

Cited: Özdemir, G., Çavuş Güngören, S. \& Yesildag-Hasançebi, F. (2022). Investigation of science learning skills of middle school students according to various variables. Pamukkale University Journal of Education, 54, 69-98, 10.9779/pauefd.799198

\footnotetext{
${ }^{*}$ This study was produced from the first author's master thesis.

** Expert in Science Education, gulcan.akbayrak5@gmail.com, ORCID ID: 0000-0002-5844-2501

*** Asst. Prof. Dr., Çanakkale Onsekiz Mart University, sdacavus@gmail.com, ORCID ID: 0000-0001-9521-0008

**** Asst. Prof. Dr., Giresun University, fndysldg@gmail.com, ORCID ID: 0000-0001-9365-940X
} 


\section{Introduction}

One of the main objectives of science education is to educate individuals who conduct investigating and questioning (Ministry of National Education [MoNE], 2013, 2018). As in the science curriculum of many countries (America-NRC, 1996, 2000; Australia - Tytler, \& Hobbs, 2011; England - The National Curriculum in England, 2013), in our country, it is aimed that the student is responsible for his/her own learning, participates actively in the process and learns the knowledge meaningfully and permanently (MONE, 2018; Next Generation Science Standards [NGSS], 2013). According to the science education criteria published by NSTA (2000) and NGSS (2013), it has been explained that all students from preschool to university should have the ability to conduct scientific research know its stages. In this context, it was suggested that the science curriculum should be planned according to the Inquiry-Based Learning (IBL) method with appropriate activities and instructional designs created in the classroom or school, in the laboratory, or in out-of-school learning environments (MoNE, 2018: p.10). IBL, which is included as "inquiry-based learning" in the literature, has been translated into Turkish by researchers with different names such as "scientific inquiry-based learning, research-based learning, inquiry-based learning, researchbased teaching” (Doğan, Han-Tosunoğlu, Özer \& Akkan, 2020; Taş, Başoğlu, Sarıgöl, Tepe \& Güler, 2018).

Bybee (2000) suggested that scientific inquiry consists of three elements: scientific inquiry skills, knowledge about scientific inquiry, and an educational approach for teaching science content. Schwartz (2004) referred to scientific inquiry as characteristics of processes in which scientific knowledge is developed, accepted, and used. Inquiry-based teaching provides a learning environment that requires individuals to research, examine, and analyze information (Perry \& Richardson, 2001; Wu, \& Krajcik, 2006). In this regard, IBL is a teaching approach in which students learn by thinking/working as scientists, either independently or in groups, using their pre-existing expertise and skills, such as the nature of science, scientific study, and approaches to clarify scientific knowledge (Schwartz, 2004). It has been defined as a process of concluding by making observations, creating questions, reviewing books, planning research, and examining it in the context of scientific evidence, and analyzing and interpreting data (National Research Council [NRC], 2000). In addition to basic scientific process skills, IBL enables one to learn about scientific research, to understand how science is different from other ways of knowing, and where scientific knowledge originates (Antink-Meyer, Bartos, Lederman, \& Lederman, 2016). 
The Science Curriculum aims to design classroom / in-school and out-of-school learning environments based on the IBL approach with an interdisciplinary approach (MoNE, 2018). Thanks to IBL, the focus of science teaching has changed, and the effective use of scientific process skills and critical thinking skills has replaced memorization in learning science-related facts and concepts (Açıkgöz \& Uluçınar Sağır, 2020). The purpose of using this approach in science education at the primary education level is to help students develop their inquiry, research, and scientific process skills (Duban, 2008). However, in the research carried out by Açıkgöz and Uluçınar-Sağır (2020) to determine the awareness of science teachers about inquiry-based teaching, it was determined that only a part of the teachers was aware of the program change for the IBL approach and those who were aware of it did not have clear information. In addition, it was determined that a small number of teachers tried to apply the inquiry-based teaching approach in their classrooms, but factors such as missing equipment, insufficient time, and large class size made the implications difficult, and students could partially fulfill the assigned tasks. This result is important for the student profile (studying, criticizing, questioning, etc.) targeted by the science curriculum.

In order for students to better understand science, they need to learn how to ask questions about specific problems and how to answer these questions based on data and evidence. Students who have experienced this process learn to find evidence from different sources, to make arguments and statements based on available information and to communicate and defend the results (Chang et al., 2011). In this respect, it is important how these skills are acquired by students in science course. In the literature, there are many studies investigating the effect of inquiry-based teaching on learning (Abd-El-Khalick, Boujaoude, Duschl, Lederman et al. 2004; Bilir \& Özkan, 2018; Cairns \& Areepattamannil, 2019; Keçeci, 2014; Timur \& Kıncal, 2010; Varlı \& Uluçınar Sağır, 2019). For example, Timur and Kincal (2010) stated that when compared to the traditional method, inquiry-based teaching does not affect students' achievement at the "knowledge" level, but significantly changes their "comprehension", "application", and "general achievement" levels. Bilir and Özkan (2018) stated that as a result of their research, students are more interested in the course designed with IBL approach, develop their hand skills, learn better by doing, have increased feelings of curiosity, have fun during learning and participate more actively in the course, while Keçeci concluded that (2014) IBL is effective in improving students' scientific process skills. 
In addition to gaining scientific process skills, having the ability to share these gains, and having scientific communication skills to carry science forward is one of the important achievements of science teaching. Processes such as reading and writing, exchanging ideas, and having scientific discussions require using these communication skills. Chang and his colleagues (2011) stated in the Organization for Economic Cooperation and Development (OECD, 2005) report that science learning skills should be evaluated in the process of evaluating students' skills, including not only basic knowledge, but also skills and knowledge practices, and communication ability in science. Therefore, it is noted that scientific communication has an important place in terms of science learning skills. As a matter of fact, in the experimental study of Wildan, Hakim, Siahaan, and Anwar (2019), it was determined that the inquiry approach had a positive effect on the communication skills of the students, and the experimental group's scores in writing, verbal and social skills were higher than the control group. It was observed that a limited number of researchers nationally conducted research on competence for science learning and communication (Aslan-Efe \& Özmen, 2018; Duran, 2014; Şenler, 2014). Therefore, research is still needed on this method, which has various positive effects on the learner (Doğan, Han-Tosunoğlu, Özer \& Akkan, 2020). Researchers have pointed out that few studies have been carried out on IBL in Turkey, quantitative methods are preferred in studies, studies using mixed methods are few and qualitative methods are not given sufficient importance in researches (Kızılaslan, Sözbilir \& Yaşar, 2012). Researches that examine this approach in depth will guide teachers in order to apply inquiry-based teaching effectively in schools. In researches carried out on IBL, experimental researches in which the effect of academic success is mostly examined and where teacher candidates are selected as examples stand out. (Alemli, 2019). When the studies investigating the effectiveness of IBL with different variables at the middle school level are examined, it is seen that they focus on academic achievement, conceptual understanding, scientific process skills and argument development levels (Bilir \& Özkan, 2018; Duran \& Dökme, 2018; Varlı \& Uluçınar Sağır, 2019). While many studies in the literature emphasize that the IBL approach increases the academic success of students in learning science, there are no studies on how this approach affects students' s competence for science learning. In addition, Varlı and Uluçınar-Sağır (2019) recommend investigating the effects of IBL on different skills of students. Examining how the ASDÖ approach affects students' competence for science learning in terms of various variables (gender, class level, parent education level, student science achievement), this study is thought to contribute to the literature. In the literature, it was determined that there was limited research in which 
competence for science learning were examined in terms of similar variables (Aslan-Efe \& Özmen, 2018). In addition, it is important to evaluate how IBL, which contributes to competence for science learning, is used in science courses through teacher and student views. In this context, research questions are determined as follows:

1. What are the competence for science learning levels of middle school students?

2. Do middle school students' competence for science learning differ by gender?

3. Do the competence for science learning of middle school students differ according to the class level?

4. Do the competence for science learning of middle school students differ according to the education level of the students' parents?

6. Do the competence for science learning of middle school students vary according to the science achievement grade?

7. What are the views of middle school students about the teaching of science course in terms of IBL?

8. What are the views of science teachers about the teaching of science course in terms of IBL?

\section{Method}

\section{Research Design}

In this study, an exploratory sequential design, one of the mixed research methods, was used. Mixed method research is an intellectual and practical synthesis based on qualitative and quantitative research. It is the third methodological (together with qualitative and quantitative research) or research paradigm (Johnson, Onwuegbuzie \& Turner, 2007). Therefore, it is a method in which qualitative and quantitative methods are used together (Yıldırım \& Şimşek, 2018: p.322). The explanatory sequence design, which is one of the types of this method, consists of two different interactive stages and starts with the collection and analysis of quantitative data and continues with the collection and analysis of qualitative data (Creswell \& Plano-Clark, 2014, p.80). In the study, qualitative data were added to the process when answering the secondary research question within the survey research from the dominant quantitative research (Creswell \& Plano Clark, 2014). Before 
starting the research, necessary permissions were obtained from the provincial directorate of national education, and a research process by publication ethics was followed.

\section{Participants}

Sequential mixed method sampling was used in the selection of the study group. Baki and Gokcek (2012) stated that the sequential mixed method is used in order of probabilistic and purposeful sampling strategies (Quantitative-Qualitative) and is one of the most used methods in mixed method research. In this sampling method, the participants in the quantitative stage by probabilistic sampling methods are determined respectively, and then the sample that will participate in the qualitative stage is selected from this sample by purposeful sampling method (Baki \& Gökçek, 2012). The participants consisted of 805 middle school students ( $53 \%$ female and $47 \%$ male) who attended different class levels in six different public schools determined by possible sampling method among schools in a provincial center in northeastern Turkey, where researchers also lived. The participants included 195 fifth graders, 194 sixth graders, 225 seventh graders, and 190 eighth graders. Four science teachers with professional experiences between 5 and 10 years who taught the course participated voluntarily in the study. The reason why teachers and students are included in the research is that the data to be obtained from the point of view of the science course in terms of IBL can be enriched not only by the perspectives of the students, but also by the views of the teachers who are the other important stakeholders of the course.

\section{Data Collection Tools}

Research data were obtained by one quantitative and two qualitative data collection tools. The quantitative data was collected through the 5-point Likert type "Competence Scale for Learnıng Science" developed by Chang et al. (2011) and adapted to Turkish by Senler (2014). Şenler's study group consists of teacher candidates. However, she stated that the scale can be used to measure the competence in scientific inquiry and competence in communication of all students from primary education to university (Şenler, 2014, p. 403). The questions in the scale consist of two subscales, competence in scientific inquiry and competence in communication, and a total of 29 items. The competence in scientific inquiry subscale has four sub-dimensions; presenting question and hypothesis, planning, experimenting, and data gathering, data analyzing, interpreting and concluding. The competence in communication subscale has four sub-dimensions of; expressing, evaluating, responding and negotiation. Students have been given one lesson hour to answer the scale. 
The views form consisting of open-ended questions and a semi-structured interview were used to obtain qualitative data. The views form and semi-structured interview questions were developed by a science teacher and two science education experts using the subscales of the competence in scientific inquiry scale and a pilot study was conducted. In addition, while developing this form, it was determined that the concepts of data, determination of variables, and hypothesis formation were included in the fourth and fifth grade acquisitions within the framework of the 2018 science curriculum. In this context, data was collected through the views form with open-ended questions with 60 middle school students selected from the schools where the data was collected. The views form was used because the number of participants was large when receiving student views. The form contains six questions for students on the process of planning and preparing the experiment (one question), experimenting (one question), saving data (one question), data analysis (one question), comparing ideas before and after the experiment (one question), and sharing results (one question).

Semi-structured interviews were conducted with four science teachers who taught the science course to the students who filled out this form. The content of the interview questions is prepared in parallel with the questions posed to the students as a total of nine questions to reach more details. In the semi-structured interviews directed to teachers, questions were asked about the process of planning and preparing the experiment (one question), experimenting (one question), saving data (one question), data analysis and interpretation (two questions), presenting data (one question), comparing ideas before and after the experiment (one question), sharing (two questions). The time given to students to fill out the form and face-to-face interviews with teachers took an average of 30-40 minutes.

\section{Data Analysis}

The Competence Scale for Learnıng Science was scored as $5=$ Strongly Agree, $4=$ Agree, 3 $=$ Undecided, $2=$ Disagree and $1=$ Strongly Disagree. Item-total correlations of the scale were calculated, and correlation values were found to be between 0.42 and 0.70 . The $27 \%$ lower and upper group averages for the item differentiation feature were compared with the independent t-test and were determined to be significant at $\mathrm{p}<.001$ for all test items. The correlation value between scientific inquiry and communication subscales was 0.77 and was found to be significant at $\mathrm{p}<.001$. As a result of the factor analysis, it was determined that the values of compliance indexes were within acceptable value limits. The data were 
analyzed in the SPSS 20 statistical program. For the normality analysis of the data obtained from the scale, the graphs (Q-Q graph and box-whisker graph) were examined, and the Kolmogorov-Smirnov test was applied, and it was determined that the data were not normally distributed $(\mathrm{p}<.05)$ as a result of the test. Nonparametric tests were preferred in data analysis because the requirement of "normal distribution of data" could not be achieved from the assumptions of parametric tests. In this context, Mann-Whitney U Test and Kruskal Wallis test, which are among the nonparametric tests, were used in the study. When the reliability of the results obtained from the scale was examined, it was observed that Şenler (2014) calculated the Cronbach's Alpha coefficients as .90 for the competence in scientific inquiry subscale, .92 for the competence in communication subscale, and .95 for the total scale. In this study, Cronbach's Alpha coefficients were determined as .86 for the competence in scientific inquiry subscale, .87 for the competence in communication subscale, and .92 for the total scale.

Content analysis was used in the qualitative dimension of the research. Content analysis is an approach that provides a deep and systematic examination of verbal, written and other materials. The stages of content analysis are specified in four steps. These are: data encoding, theme creation, editing, and interpretation (Yıldırım \& Şimşek, 2018: p.243). In this context, the data obtained from the students through the form containing open-ended questions were coded and combined under a common theme. In the interviews with the teachers, the audio recordings were listened to and transcribed, and the answers to the questions were coded and analyzed. For the internal validity of the data, long-term interaction, deep-focused data collection, diversification, expert review, and participant confirmation were obtained during the interviews. A purposeful sample selection was made with students and their teachers selected from the participants of the group in which quantitative data was obtained for external validity, and detailed descriptions were included. For internal reliability, the process of collecting the data was consistent and the same questions were asked to all participants, and consistent coding was taken into consideration in the analysis. External reliability is provided by expert confirmation and a one-to-one quote, like the presentation of sample discourses. 


\section{Findings}

\section{Competence for Science Learning Levels of Middle School Students}

In the study, the competence for science learning levels of middle school students were analyzed according to the subscales of scientific inquiry and communication. The relevant results are presented in Table 1.

Table 1. Competence for Science Learning Levels of Middle School Students

\begin{tabular}{|c|c|c|c|c|}
\hline Subscale & Sub-dimensions & $\mathrm{N}$ & $\overline{\mathrm{x}}$ & ss \\
\hline \multirow[t]{4}{*}{ Scientific inquiry } & Presenting question and hypothesis & 805 & 4.21 & .60 \\
\hline & Planning & 805 & 4.00 & .72 \\
\hline & Experimenting and data gathering & 805 & 4.09 & .77 \\
\hline & $\begin{array}{l}\text { Data analyzing, interpreting, and } \\
\text { concluding }\end{array}$ & 805 & 4.08 & .68 \\
\hline \multirow[t]{4}{*}{ Communication } & Expression & 805 & 4.03 & .73 \\
\hline & Evaluation & 805 & 4.16 & .66 \\
\hline & Responding & 805 & 4.15 & .73 \\
\hline & Negotiation & 805 & 4.17 & .70 \\
\hline
\end{tabular}

When Table 1 is examined, it is determined that the competence for science learning levels of the students is above average four of the scientific inquiry and communication subscales.

\section{Investigation of Middle School Students' Competence for Science Learning,} Competence in Scientific Inquiry and Competence in Communication According to

\section{Gender Variable}

In the study, the competence for science learning levels of middle school students were examined in terms of gender variable and it was determined that there was a difference. Related results are given in Table 2. 
Table 2. Comparison of Competence for Science Learning by Gender Variable

\begin{tabular}{|c|c|c|c|c|c|c|c|}
\hline Subscale & $\begin{array}{c}\text { Gender } \\
*\end{array}$ & $\mathrm{~N}$ & $\begin{array}{c}\text { Average } \\
\text { Rank }\end{array}$ & Rank-Sum & $U$ & $\mathrm{Z}$ & $\mathrm{p}$ \\
\hline \multirow{2}{*}{$\begin{array}{l}\text { Competence for } \\
\text { science learning }\end{array}$} & $\mathrm{F}$ & 427 & 423.20 & 180704.50 & \multirow[t]{2}{*}{71652.50} & \multirow[t]{2}{*}{-2.689} & \multirow[t]{2}{*}{.00} \\
\hline & M & 377 & 379.06 & 142905.50 & & & \\
\hline \multirow{2}{*}{$\begin{array}{l}\text { Scientific inquiry } \\
\text { subscale }\end{array}$} & $\mathrm{F}$ & 427 & 420.65 & 179619.00 & \multirow[t]{2}{*}{72738.00} & \multirow[t]{2}{*}{-2.36} & \multirow[t]{2}{*}{.01} \\
\hline & M & 377 & 381.94 & 143991.00 & & & \\
\hline \multirow{2}{*}{$\begin{array}{l}\text { Presenting } \\
\text { question and } \\
\text { hypothesis }\end{array}$} & $\mathrm{F}$ & 427 & 402.75 & 171972.50 & \multirow[t]{2}{*}{80594.50} & \multirow[t]{2}{*}{-.03} & \multirow[t]{2}{*}{.97} \\
\hline & M & 378 & 403.29 & 152442.50 & & & \\
\hline \multirow[t]{2}{*}{ Planning } & $\mathrm{F}$ & 427 & 413.88 & 176726.50 & \multirow[t]{2}{*}{75630.50} & \multirow[t]{2}{*}{-1.49} & \multirow[t]{2}{*}{.14} \\
\hline & M & 377 & 389.61 & 146883.50 & & & \\
\hline \multirow{2}{*}{$\begin{array}{l}\text { Experimenting } \\
\text { and data } \\
\text { gathering }\end{array}$} & $\mathrm{F}$ & 427 & 430.96 & 184019.50 & \multirow[t]{2}{*}{68764.50} & \multirow[t]{2}{*}{-3.67} & \multirow[t]{2}{*}{.00} \\
\hline & M & 378 & 371.42 & 140395.50 & & & \\
\hline \multirow{2}{*}{$\begin{array}{l}\text { Data } \\
\text { analyzing, } \\
\text { interpreting, } \\
\text { and concluding }\end{array}$} & $\mathrm{F}$ & 427 & 416.39 & 177800.50 & \multirow[t]{2}{*}{74983.50} & \multirow[t]{2}{*}{-1.75} & \multirow[t]{2}{*}{.08} \\
\hline & M & 378 & 387.87 & 146614.50 & & & \\
\hline \multirow{2}{*}{$\begin{array}{l}\text { Communication } \\
\text { subscale }\end{array}$} & $\mathrm{F}$ & 427 & 425.66 & 181758.00 & \multirow[t]{2}{*}{71026.00} & \multirow[t]{2}{*}{-2.94} & \multirow[t]{2}{*}{.00} \\
\hline & M & 377 & 377.40 & 142657.00 & & & \\
\hline \multirow{2}{*}{ Expression } & $\mathrm{K}$ & 427 & 407.39 & 174111.50 & \multirow[t]{2}{*}{7862.50} & \multirow[t]{2}{*}{-.621} & \multirow[t]{2}{*}{.53} \\
\hline & $\mathrm{E}$ & 378 & 387.87 & 150303.50 & & & \\
\hline \multirow{2}{*}{ Evaluation } & $\mathrm{K}$ & 427 & 413.18 & 176426.50 & \multirow[t]{2}{*}{76357.50} & -1.33 & .18 \\
\hline & $\mathrm{E}$ & 378 & 391.50 & 147988.50 & & & \\
\hline Resnondino & K & 427 & 424.08 & 181082.50 & 71701.0 & -2.77 & .00 \\
\hline & E & 378 & 379.19 & 143332.50 & & & \\
\hline Neoot & $\mathrm{K}$ & 427 & 434.68 & 185609.50 & 67174.50 & -4.14 & .00 \\
\hline & E & 378 & 367.21 & 138805.50 & & & \\
\hline
\end{tabular}

*F: Female, M: Male 
When Table 2 was examined, a statistically significant difference was found between the averages of the competence for science learning scores of female students (423.20) and the averages of the male students (379.06) according to the Mann-Whitney U test results $[\mathrm{U}=71652.5, \mathrm{p}<.05]$. It is understood that this difference is in favor of female students when their average scores are compared. When the subscales of the scientific inquiry were examined separately, it was determined that the scores of the students from the scientific inquiry subscale $[\mathrm{U}=72738.00, \mathrm{p}<.05]$ and the scores they received from the communication subscale $[\mathrm{U}=71026.00, \mathrm{p}<.05]$ also differed in favor of the female students.

When the sub-dimensions in the scientific inquiry subscale are examined separately, it is seen that there is a statistically significant difference only between the averages of the order of experimenting and data gathering of female students (430.96) and the averages of the order of experimenting and data gathering of male students (371.42) [U=68764.50, $\mathrm{p}<.05]$. When the sub-dimensions in the communication subscale were examined separately, it was determined that there was only a significant difference in the two sub-dimensions. There was a statistically significant difference in the average number of respondings of female students (424.08) and the average of responding sequences of male students (379.19) $[\mathrm{U}=71701.0, \mathrm{p}<.05]$. Similarly, it was determined that there was a statistically significant difference between the average order of communication of female students (434.68) and the averages of male students (367.21) [U=67174.50, $\mathrm{p}<.05]$.

\section{Investigation of Middle School Students' Competence for Science Learning in Terms of Grade Level}

Middle school students' competence for science learning were examined in terms of grade level, and according to the results of the comparison, it was determined that the scientific inquiry subscale differs according to the grade level. Related results are given in Table 3. 
Table 3. Examination of middle school students' science learning skills in terms of grade level

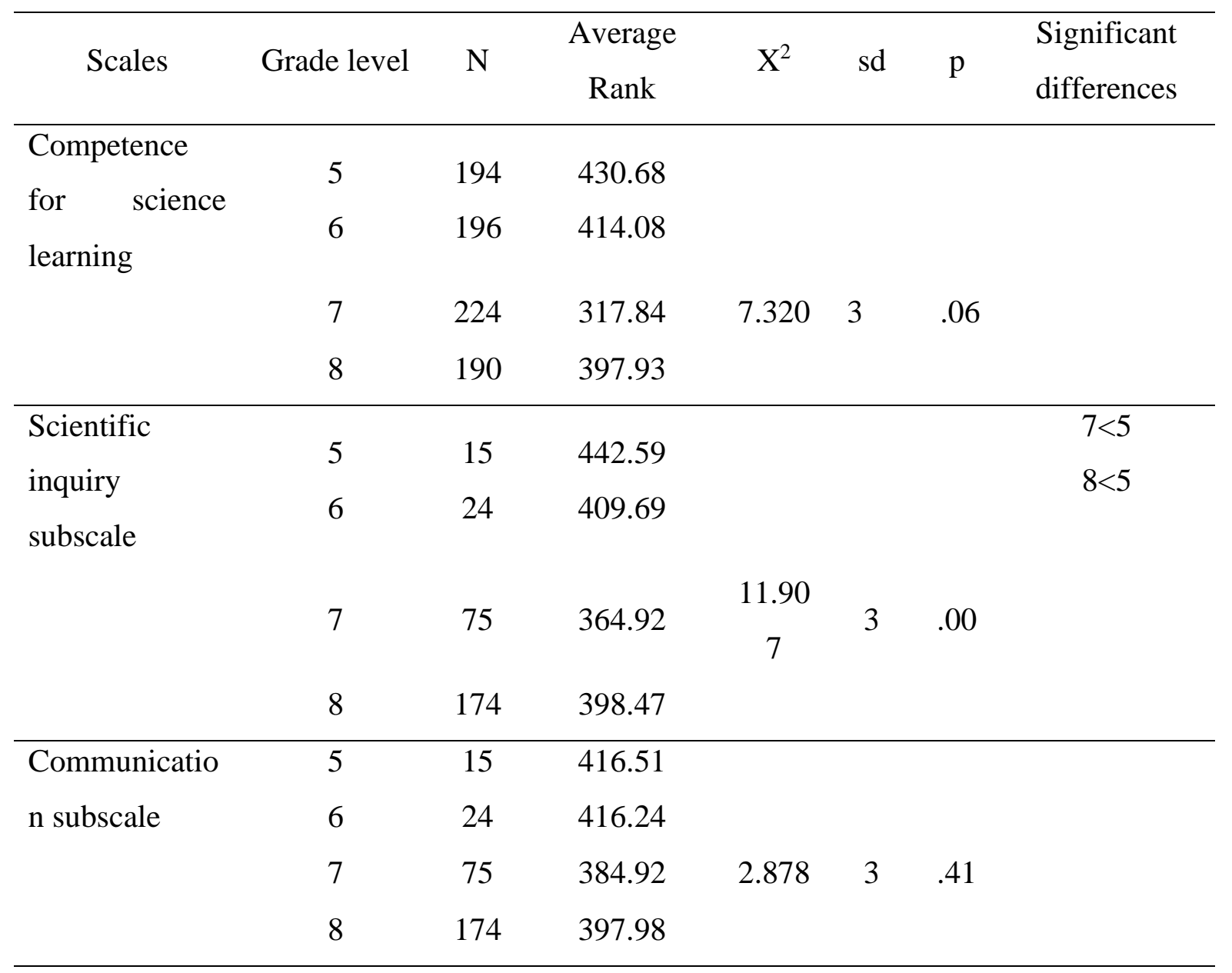

When Table 3 is examined, there is no significant difference between students' competence for science learning in terms of grade level $\left(x^{2}(3)=7.320, p>05\right)$, and there is no significant difference in the communication subscale of the scale by grade level $\left(\mathrm{x}^{2}(3)\right.$ $=2.878, \mathrm{p}>.05)$. However, it was determined that there is a significant difference $\left(\mathrm{x}^{2}(3)\right.$ $=11.907, \mathrm{p}<.05)$ in favor of higher grade levels in the scientific inquiry subscale. A significant difference was found between 8th and 5th grade students and between 7 th and 5 th grade students in favor of the lower grade level. 


\section{Investigation of Middle School Students' Competence for Science Learning in Terms of}

\section{Mother's Education Level}

Statistically significant differences were found when the science skills of middle school students were examined according to mother's education level. Results are given in Table 4.

Table 4. Investigation of the Competence for Science Learning of Middle School Students According to the Mothers' Education Level

\begin{tabular}{|c|c|c|c|c|c|c|c|}
\hline Scales & Education Level & $\mathrm{N}$ & $\begin{array}{c}\text { Average } \\
\text { Rank }\end{array}$ & $X^{2}$ & $\begin{array}{l}\mathrm{s} \\
\mathrm{d}\end{array}$ & $\mathrm{p}$ & $\begin{array}{l}\text { Significant } \\
\text { differences }\end{array}$ \\
\hline \multirow{5}{*}{$\begin{array}{l}\text { Competence } \\
\text { for science } \\
\text { learning }\end{array}$} & 1. Primary School & 173 & 366.37 & & & & \multirow{5}{*}{$\begin{array}{l}3>1,4>1, \\
5>1,3>2,4>2, \\
5>2,5>3,5>4\end{array}$} \\
\hline & 2. Middle School & 189 & 337.34 & & & & \\
\hline & 3. High School & 233 & 450.63 & 37.50 & 4 & .00 & \\
\hline & 4.University & 175 & 424.19 & & & & \\
\hline & 5. Postgraduate & 34 & 507.07 & & & & \\
\hline \multirow{5}{*}{$\begin{array}{l}\text { Scientific } \\
\text { inquiry } \\
\text { subscale }\end{array}$} & 1. Primary School & 173 & 367.96 & \multirow{5}{*}{38.581} & \multirow{5}{*}{4} & \multirow{5}{*}{.00} & $3>1,4>1,5>1$ \\
\hline & 2.Middle School & 189 & 336.89 & & & & $3>2,4>2,5>2$, \\
\hline & 3. High School & 233 & 446.28 & & & & $5>3,5>4$ \\
\hline & 4.University & 175 & 425.18 & & & & \\
\hline & 5. Postgraduate & 34 & 526.26 & & & & \\
\hline \multirow{5}{*}{$\begin{array}{l}\text { Communicati } \\
\text { on subscale }\end{array}$} & 1. Primary School & 173 & 367.69 & \multirow{5}{*}{31.556} & \multirow{5}{*}{4} & \multirow{5}{*}{.00} & $3>1,4>1,5>1$, \\
\hline & 2.Middle School & 189 & 342.58 & & & & $3>2,4>2,5>2$, \\
\hline & 3. High School & 233 & 451.93 & & & & $5>3$ \\
\hline & 4.University & 175 & 424.57 & & & & \\
\hline & 5. Postgraduate & 34 & 470.74 & & & & \\
\hline
\end{tabular}

In the entire scale of students' competence for science learning $\left(x^{2}(4)=37.50, p<.05\right)$, scientific inquiry subscale $\left(\mathrm{x}^{2}(4)=38.581, \mathrm{p}<.05\right)$ and communication subscale $\left(\mathrm{x}^{2}(4)=\right.$ 
$31.556, \mathrm{p}<.05$ ) were found to differ significantly in favor of mother's education level (Table

4). There is a difference between the results of the science skills and subscales (scientific inquiry and communication) of the students whose mother education level is high school and above, and the children of mothers with primary and middle school education levels.

\section{Investigation of Middle School Students' Competence for Science Learning in Terms of}

\section{Father's Education Level}

When the competence for science learning of middle school students were examined according to the education level of their fathers, statistically significant differences were found. Related results are given in Table 5.

Table 5. Investigation of the Competence for Science Learning of Middle School Students According to the Fathers' Education Level

\begin{tabular}{|c|c|c|c|c|c|c|c|}
\hline Scales & Education Level & $\mathrm{N}$ & $\begin{array}{c}\text { Average } \\
\text { Rank }\end{array}$ & $X^{2}$ & $\begin{array}{l}\mathrm{s} \\
\mathrm{d}\end{array}$ & $\mathrm{p}$ & $\begin{array}{l}\text { Significant } \\
\text { differences }\end{array}$ \\
\hline \multirow{6}{*}{$\begin{array}{l}\text { Competence } \\
\text { for science } \\
\text { learning }\end{array}$} & 1. Primary & 116 & 343.42 & & & & \multirow{6}{*}{$\begin{array}{l}3>1,4>1,5>1 \\
3>2,4>2,5>2\end{array}$} \\
\hline & School & & & & & & \\
\hline & 2.Middle School & 166 & 336.81 & & & & \\
\hline & 3. High School & 253 & 416.57 & 39.66 & 4 & .00 & \\
\hline & 4.University & 222 & 442.06 & & & & \\
\hline & 5. Postgraduate & 47 & 517.53 & & & & \\
\hline \multirow{6}{*}{$\begin{array}{l}\text { Scientific } \\
\text { inquiry } \\
\text { subscale }\end{array}$} & 1. Primary & 116 & 333.08 & & & & \multirow{6}{*}{$\begin{array}{l}3>1,4>1,5>1 \\
3>2,4>2,5>2\end{array}$} \\
\hline & School & & & & & & \\
\hline & 2.Middle School & 100 & 359.93 & & & & \\
\hline & 3. High School & 253 & 415.59 & 42.832 & 4 & .00 & \\
\hline & 4.University & 222 & 444.45 & & & & \\
\hline & 5. Postgraduate & 47 & 520.71 & & & & \\
\hline \multirow{2}{*}{$\begin{array}{l}\text { Communica } \\
\text { tion }\end{array}$} & 1. Primary & 116 & 356.56 & & & & $3>1,4>1,5>1$ \\
\hline & School & 166 & 342.56 & & & & $3>2,4>2,5>2$ \\
\hline
\end{tabular}




\begin{tabular}{|c|c|c|c|c|c|c|}
\hline subscale & 2.Middle Schoo & & & & & \\
\hline & 3. High School & 253 & 418.08 & 29.307 & 4 & .00 \\
\hline & 4.University & 222 & 435.18 & & & \\
\hline & 5. Postgraduate & 47 & 499.14 & & & \\
\hline
\end{tabular}

When table 5 was examined, it was determined that there was a significant difference in both the students' competence for science learning scale $\left(\mathrm{x}^{2}(4)=39.66, \mathrm{p}<.05\right)$ and scientific inquiry subscale $\left(\mathrm{x}^{2}(4)=42.832, \mathrm{p}<.05\right)$ and communication subscale $\left(\mathrm{x}^{2}(4)\right.$ $=29.307, \mathrm{p}<.05)$. There is a difference between the results of the competence for science learning scale and subscales (scientific inquiry and communication) of the students whose father education level is high school and above, and the children of fathers at the elementary and middle school education level.

\section{Investigation of Middle School Students' Competence for Science Learning According to their Science Course Grade}

When the competence for science learning of middle school students were examined according to their science course grades (science course grade in the last academic year), it was determined that there was a difference. Relevant results are given in Table 6.

Table 6. Comparison of the Competence for Science Learning of Middle School Students in Terms of Their Science Course Grade

\begin{tabular}{|c|c|c|c|c|c|c|c|}
\hline Scales & $\begin{array}{c}\text { Science } \\
\text { Course Grade }\end{array}$ & $\mathrm{N}$ & $\begin{array}{c}\text { Average } \\
\text { Rank }\end{array}$ & $X^{2}$ & $\mathrm{sd}$ & $\mathrm{p}$ & $\begin{array}{l}\text { Significant } \\
\text { differences }\end{array}$ \\
\hline \multirow{5}{*}{$\begin{array}{l}\text { Competence } \\
\text { for science } \\
\text { learning }\end{array}$} & 1 & 15 & 237.93 & & & & $5>1$ \\
\hline & 2 & 24 & 231.50 & & & & $4>1$ \\
\hline & 3 & 75 & 312.46 & 64.781 & 4 & .00 & $4>2$ \\
\hline & 4 & 174 & 339.56 & & & & $5>2$ \\
\hline & 5 & 514 & 339.56 & & & & \\
\hline Scientific & 1 & 15 & 283.03 & & & & $5>1$ \\
\hline
\end{tabular}




\begin{tabular}{|c|c|c|c|c|c|c|c|}
\hline \multirow{4}{*}{$\begin{array}{l}\text { inquiry } \\
\text { subscale }\end{array}$} & 2 & 24 & 234.63 & \multirow{4}{*}{61.194} & \multirow{4}{*}{4} & \multirow{4}{*}{.00} & $4>1$ \\
\hline & 3 & 75 & 318.63 & & & & $4>2$ \\
\hline & 4 & 174 & 334.12 & & & & $5>2$ \\
\hline & 5 & 514 & 447.65 & & & & \\
\hline \multirow{5}{*}{$\begin{array}{l}\text { Communicati } \\
\text { on subscale }\end{array}$} & 1 & 15 & 242.20 & \multirow{5}{*}{54.047} & & \multirow{5}{*}{.00} & $5>1$ \\
\hline & 2 & 24 & 243.90 & & & & $4>2$ \\
\hline & 3 & 75 & 311.82 & & 4 & & $4>1$ \\
\hline & 4 & 174 & 353.37 & & & & $5>2$ \\
\hline & 5 & 514 & 443.76 & & & & \\
\hline
\end{tabular}

When table 6 was examined, it was determined that there was a significant difference in both the entire competence for science learning scale $\left(x^{2}(4)=64.781, p<.05\right)$ and the scientific inquiry subscale $\left(\mathrm{x}^{2}(4)=61.194, \mathrm{p}<05\right)$ and communication subscale $\left(\mathrm{x}^{2}(4)\right.$ $=54.047, \mathrm{p}<05)$ in favor of the successful student. The results of competence for science learning scale and subscales (scientific inquiry and communication) of students with a science course grade of four and above are higher than those of students with lower success (with a success grade of one or two).

\section{Middle School Students' Views Regarding the Teaching of Science Course in terms of} IBL

Students' views were taken through open-ended questions about the way the science course is taught in terms of IBL. Experimental preparation, experimental process, saving of experiment data, analysis of data, comparison of pre- and post-experiment ideas, result sharing themes were determined, and sample discourses are given in Table 7. 
Table.7. Findings Regarding Students' Views About the Teaching of Science Course in terms of IBL

\begin{tabular}{|c|c|c|c|}
\hline Theme & Code & $\mathrm{f}$ & Sample discourses \\
\hline Experiment & Creating a & 12 & Ö1: There is a question given before experimenting. \\
\hline \multirow[t]{5}{*}{ Preparation } & question & 8 & Ö2: We formulate hypotheses and answer \\
\hline & Setting up a & 3 & questions. \\
\hline & hypothesis & 2 & Ö3: We prepare questions before the experiment, \\
\hline & Preparing material & & and after the experiment, we find the answers to the \\
\hline & Not preparing & & questions. \\
\hline \multirow{7}{*}{$\begin{array}{l}\text { The } \\
\text { Experimenti } \\
\text { ng Process }\end{array}$} & Active & 10 & Ö6: Everyone has a role and I am actively involved. \\
\hline & participation & 8 & Ö3: Sometimes we participate and sometimes we \\
\hline & Monitoring the & 5 & watch. \\
\hline & experiment & 4 & Ö5: We are bringing the materials that our teacher \\
\hline & Teacher assistance & 3 & asks us to bring from home. I have no role. \\
\hline & Not taking part & & Ö4: The experiments are so much fun, my role is to \\
\hline & Collaborating & & $\begin{array}{l}\text { come up with an idea and I'm actively trying to } \\
\text { participate. }\end{array}$ \\
\hline \multirow{3}{*}{$\begin{array}{l}\text { Saving } \\
\text { Experiment } \\
\text { Data }\end{array}$} & Note taking & 18 & $\begin{array}{l}\text { Ö3: I'm taking more notes. But we also draw a } \\
\text { table in the experiment notebook. }\end{array}$ \\
\hline & $\begin{array}{l}\text { Creating charts } \\
\text { and tables }\end{array}$ & 10 & $\begin{array}{l}\text { Ö1: The use of graphics and tables varies } \\
\text { according to the subject. }\end{array}$ \\
\hline & $\begin{array}{l}\text { Mathematical } \\
\text { expression }\end{array}$ & 2 & $\begin{array}{l}\text { Ö4: We use mathematical expressions according to } \\
\text { our topics. }\end{array}$ \\
\hline Data & Comparing data & 10 & Ö4: We make use of comparison techniques. \\
\hline \multirow[t]{4}{*}{ Analysis } & Note taking & 4 & Ö1: I analyze it with the help of tables or graphs. \\
\hline & $\begin{array}{l}\text { Analysis with } \\
\text { tables or graphs }\end{array}$ & 2 & $\begin{array}{l}\text { Ö2: I collect all the data and share my ideas to } \\
\text { come to a general conclusion. }\end{array}$ \\
\hline & Sharing ideas & 2 & Ö3: I can come to conclusions, and when I can't, I \\
\hline & Doing research & 2 & investigate. \\
\hline
\end{tabular}




\begin{tabular}{|c|c|c|c|}
\hline $\begin{array}{l}\text { Comparing } \\
\text { Before and }\end{array}$ & Yes & 22 & $\begin{array}{l}\text { Ö1: Yes. Sometimes we reach the right conclusion } \\
\text { by using ideas and logic. }\end{array}$ \\
\hline \multirow[t]{3}{*}{ After Den } & Sometimes & 9 & Ö2: Sometimes my thoughts change. But it usually \\
\hline & No & 5 & does. \\
\hline & & & Ö3: No because I am doing what is on my mind. \\
\hline Sharing & Yes & 18 & Ö3: Yes. I'm comparing them by taking everyone's \\
\hline \multirow[t]{4}{*}{ Results } & No & 6 & views. It helps me come to an overall conclusion. \\
\hline & Sometimes & 4 & Ö4: Sometimes. I can understand it more by myself. \\
\hline & & & I ask my teacher what I don't understand. \\
\hline & & & Ö5: Yes. What I don't see, I see from my friends. \\
\hline
\end{tabular}

According to the results of the study, students usually stated that they started the experiment with a question ( $\mathrm{f}=12)$ or hypothesis $(\mathrm{f}=8)$ when asked what was done before starting the experiment (Table 7). Students stated that they usually take an active role in the experimental phase by taking an active role in the process $(\mathrm{f}=10)$ and watching according to the condition of the experiment $(\mathrm{f}=8)$. The students stated that saving the experimental data was mostly in the form of note-taking $(f=18)$ and they could also draw graphics or tables ( $f$ $=10$ ) according to the subject. The students stated that they did so more by comparing the results of the analysis $(f=10)$. Students stated that there is usually a change in their beforeexperimenting ideas $(\mathrm{f}=22)$ after conducting experiments. In addition, the students stated that they generally shared the results they obtained at the end of the experiment with their friends $(f=18)$.

\section{Science Teachers' Views about the Instruction of Science Course in terms of IBL}

Teachers have been consulted through open-ended questions about the way the science course is taught in terms of IBL. The themes of experiment preparation, experimental process, saving experiment data, analysis of data, presenting analysis results, comparing and sharing pre- and post-experiment ideas were determined and sample discourses were presented in Table 8. 
Table 8. Findings Regarding Teachers' Views about the Instruction of Science Course in terms of IBL

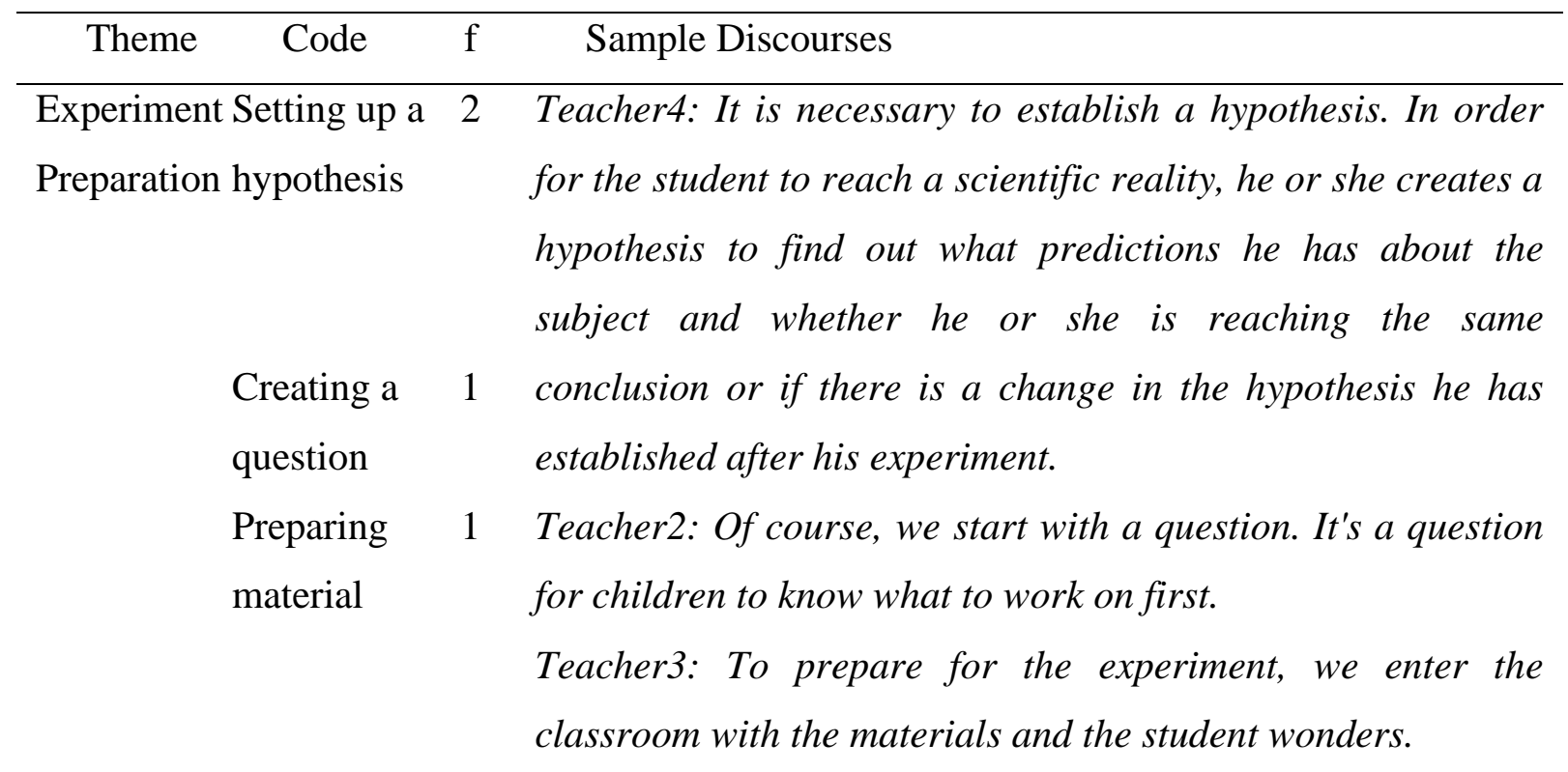

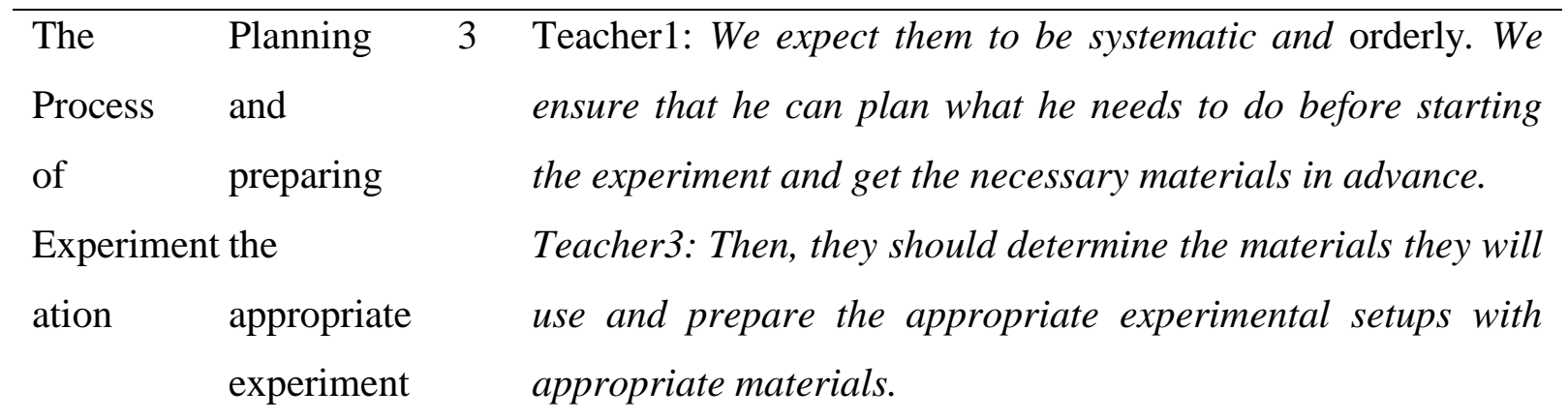
$\begin{array}{lll}\text { Saving } \quad \text { Note taking } & 2 & \text { Teacher3: Often students interested in experimenting prefer to }\end{array}$ Experiment take notes in the data collection process.
Data Making 2 Teacher2: If they measure things based on time, we want them chart and to save them as tables, and if there are variables such as table increase or decrease, we want them to show them in a graph.

\begin{tabular}{llll}
\hline $\begin{array}{l}\text { Data } \\
\text { Analysis }\end{array}$ & $\begin{array}{l}\text { Analyzing } \\
\text { with tables }\end{array}$ & 2 & $\begin{array}{l}\text { Teacherl: When we do experiment about speed, they already } \\
\text { have to evaluate the results of the analysis through the graph. } \\
\end{array}$ \\
& /graphics & When experiments are on heat and temperature, graphs are \\
\hline
\end{tabular}


Inability to 1 always used.

analyze

Teacher2: We do not have an experiment room, they cannot analyze because we do it in the classroom. What we do at school is just experiments to show students. The student, of course, tells what he understood in the experiment rather than his own thoughts after doing the experiment.

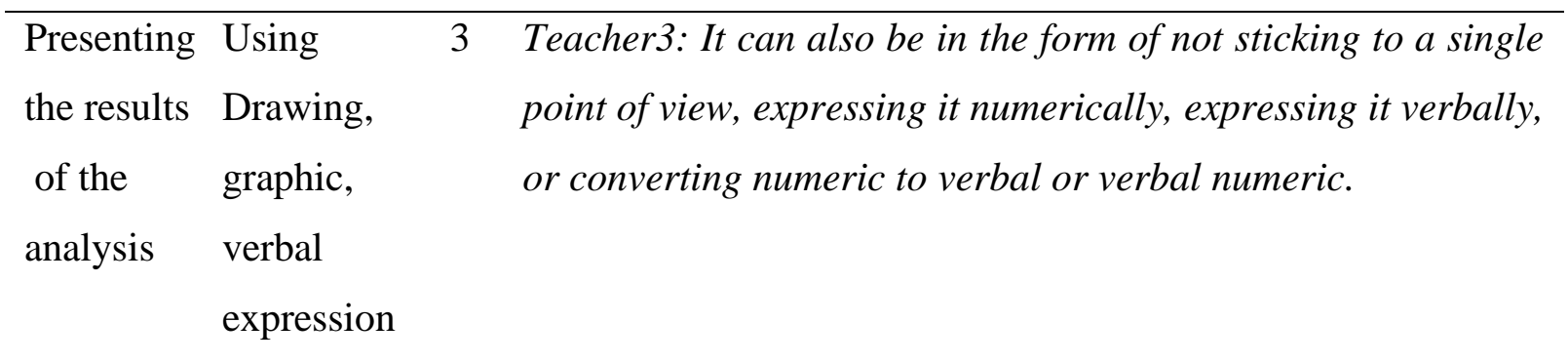

Pre- and 4 Teacher2: When they do experiment, they are convinced. If
Post- Compariso they find results that are different from their own, of course, Experiment $n$ they react. Because each group wants to believe their results Compariso are correct. Along with this belief, they can judge each other, $\mathrm{n}$ want to correct where they find it wrong.

Teacher4: Actually, the thought of judgment is a bit incomplete when analyzing your own arguments or those of other friends.

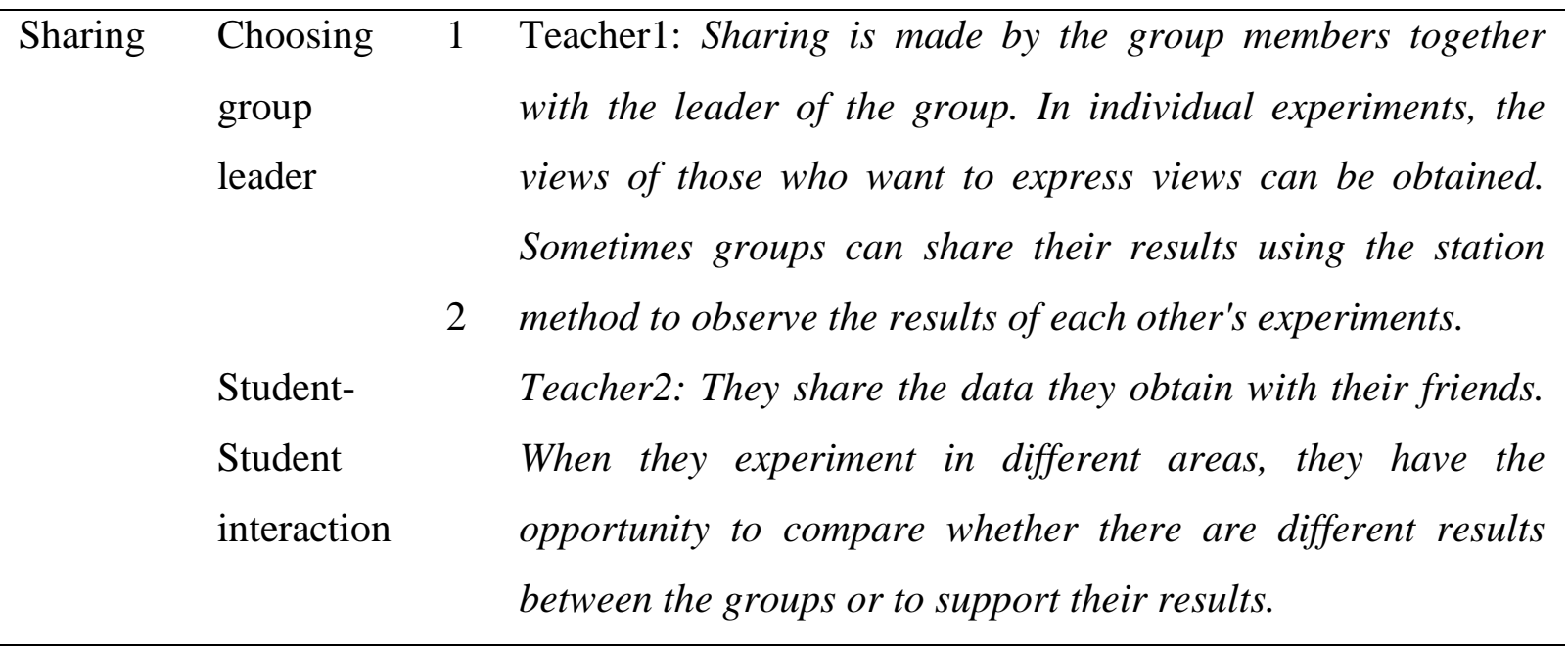

After the interviews with the teachers, it was found that they believed the necessity to start the lesson with a hypothesis $(f=2)$ or a question ( $f=1)$ before starting an activity or experiment applied in the lesson for the students, and they guided the students on this issue (Table 8). They stated that they wanted students to take notes ( $f=2)$, draw graphics or create a table $(\mathrm{f}=2$ ) to actively participate in the data collection process. In addition, it was 
determined that there were teachers who preferred the use of graphics ( $f=2)$ in the analysis of the data, as well as the teacher ( $f=1$ ) who stated that the students could not analyze after the experiment because the experiments were not carried out in the laboratory environment. It was determined that the use of drawing, graphics, and verbal expressions ( $f=3$ ) was preferred in the presentation of analysis results. When they compared the students' thoughts before and after the experiment, they stated that in the group studies, most of them compared the results they found at the end of the process with the results of the other group $(f=4)$. From time to time, they criticized the results of the opposite group or noted that there may be competition between them. Teachers stated that students shared the results of the experiment with their friends, sometimes selecting the group leader $(\mathrm{f}=1)$ and sometimes replacing them with other groups $(\mathrm{f}=2)$, observing the results, communicating with each other through discussions.

\section{Discussion and Conclusion}

In this study, the competence for science learning of middle school students at different grade levels were examined according to various variables. Because inquiry-based teaching is a teaching method that has the potential to improve students' scientific literacy by increasing both their understanding of science and their interest in science (Capps, \& Crawford, 2013). As in many countries, the use of this teaching strategy has been recommended in our country (NRC, 1996, 2000; Tytler, \& Hobbs, 2011; MoNE, 2005, 2008, 2013) and its effects have been deemed valuable. Accordingly, the results showed that the competence for science learning levels of middle school students participating in the study were above average. It was determined that the scientific inquiry and communication competence of the students, which are sub-subscales of competence for science learning scale, were also above average. In the qualitative dimension of the study, both students' and teachers' views on the teaching of science courses in terms of IBL support quantitative results and that the IBL environment is provided in science courses. Teachers stated that they encourage students to question in their lessons and direct them when necessary. They stated that they guided the students about what kind of steps they should follow in the process of experimenting, how they should analyze it when a scientific result is obtained at the end of the process, and how they should evaluate the analysis results. Duran (2015) stated that science couse supported by guiding activities in her research did not have a significant effect on students' inquiry learning skills. It can be stated that the teacher's 
guidance to the students during the inquiry process and the students' ready-made guidance activities affect their questioning skills differently when comparing the results. However, in this study, it is thought that guiding the students during the inquiry process has positive results. Therefore, teachers are required to direct students to the inquiry process and also guide them when necessary (Dobbler, Zward, Tanis, \& Oers, 2017). The students stated that they are usually active in the inquiry process, and that when they reach a scientific conclusion, their thoughts before the experiment may change after conducting the experiment. It is an indication that students are experiencing a learning environment based on research and inquiry, stating that they have carried out the stages of preparing research questions or hypotheses, conducting experiments, collecting data, analyzing, and sharing it with other friends. This situation partially explains the reason why competence for science learning is above average in the quantitative dimenson of the research.

With IBL, female and male students are given the opportunity to discover and support their own ideas within the curriculum (Wolf \& Fraser, 2008). However, in this study, when the competence for science learning of female students were compared with the competence for science learning of male students, it was observed that the results were in favor of females and this was in parallel with the research results of Aslan-Efe and Özmen (2018). On the other hand, Wolf and Fraser's (2008) inquiry-based laboratory activities were found to be differently effective for male and female students. It was determined that males benefited more from the effects of the inquiry-based method, whereas females benefited more from non-inquiry-based approaches, especially in issues such as attitude towards science, classroom task sharing, cooperation, and equality. Although the reasons for the difference by gender are not questioned in this study, the presence of similar results or the possible causes are valuable topics and researchers are advised to focus on them.

When the subscales of the competence for science learning scale were examined separately, it was determined that the scores the students got from the scientific inquiry subscale and the scores they got from the communication subscale were in favor of the female students. When the sub-dimensions of the scientific inquiry subscale were examined, it was observed that the average of female students was higher than the average of male students in the sub-dimension of experimenting and collecting gathering. These findings of the study are similar to the studies conducted by Şenler (2014) and Aslan-Efe and Özmen (2018). On the other hand, Duran (2014) stated that there is no difference in communication and inquiry competences of 7 th grade students according to their gender, and their inquiry 
competence increase in parallel with their communication competence. It is recommended to re-evaluate these differences in the results of the studies based on gender variability.

Inquiry-based learning is collaborative learning, and in this learning, male and female students gather in the same group where they collaborate in the educational process to solve a problem that needs to be solved (Nunaki, Damopolii, Kandowangko, \& Nusantari, 2019). This is because teachers often direct students to experiment with the group for economic reasons and communicate more during this collaborative process and allow students to have the opportunity to express themselves more (Raviv, Cohen, \& Aflalo, 2019). Aydin (2016) stated that inquiry-based practices affect students' communication competence as they require evaluating claims, researching ideas, solving problems, drawing valid conclusions, and developing arguments based on evidence, and prepare them for both social life and professional careers. In this study, when the sub-dimensions in the communication subscale were examined according to the gender variable, it was determined that the sub-dimensions of responding and negotiating were again significant in favor of female students. Based on these findings, it can be concluded that female students have higher comptence levels than male students in terms of experimenting and collecting data in the name of scientific inquiry during classroom science events, as well as interacting and negotiating in terms of communication during these activities. Duran (2014) found that while her research did not observe a gender-oriented difference, students had the ability to express themselves, which is a sub-dimesions of communication competence, but did not find them sufficient in their ability to ask questions. In the qualitativeof the study, although no gender-based assessment was made, the statements about the processes of taking an active role during the experiment, comparing analysis results, and sharing with friends reflect the importance of having adequate communication in the IBL environment. Communication techniques used by teachers in this process are also important because the communication subscale scores of the students participating in the research are above the average.

When the competence for science learning of middle school students were examined according to the parental education level, it was determined that there was significant difference both in the entire scale of competence for science learning and in the subscales of scientific inquiry and communication. It can be said that the competence for science learning of students whose parents' education level is high school and above may be higher. AslanEfe and Özmen (2018) also found that the competence for science learning of the students 
were related to the educational level of the parents and stated that the skills of those whose parents graduated from university were higher than those whose parents graduated from primary and middle school. Considering that parents with a high level of education have a supportive attitude in terms of education (Özer \& An1l, 2011), it can be said that this situation positively reflects on children's achievements. MoNE's central examination report on middle education institutions in 2020 also showed that the increase in the level of education of parents reflected positively on the exam scores of students (MoNE, 2020).

One of the important findings of the study is that the student with high science achievement has high competence for science learning, scientific inquiry, and communication competence. The results of the competence for science learning and subscales of students with a science course grade of four and above are higher than those of students with lower grades. Varlı and Uluçınar Sağır (2019) concluded that IBL has positive effects on students' academic achievement, competence for science learning, and metacognition. Sarı and Şaşmaz Ören (2020) also concluded that its positive effect on students' academic success is more compared to other teaching methods. However, it should not be judged from these results that IBL is better than other teaching methods. As a matter of fact, Gülhan and Yurdatapan (2014) found that there was no significant difference in the attitudes and behaviors of the 5th grade students at the middle school experimental group and the control group where IBL was applied. In addition, Cairns and Areepattamannil (2019), in their comprehensive study including data from many countries, revealed a negative relationship between student, school and country level demographic characteristics and students' tendencies towards science, the increasing frequency of IBL, and science course achievement. The reason for this negativity may be related to the quality of research inquiry-based teaching experienced by students (Cairns \& Areepattamannil, 2019). Because inquiry-based instruction has a significant positive relationship with scientific attitudes such as curiosity and enjoyment in science learning, enthusiasm for the future related to science, self-competency, and self-sufficiency according to the researchers. (Cairns \& Areepattamannil, 2019).

As a result of comparing the students' competence for science learning in terms of grade level, it was determined that there was no significant difference between the competence for science learning of the students, and that there was a significant difference between the 8th and 5th grade students and between the 7th and 5th grade students in favor of the grade level. These results show that students' competence for science learning differs 
according to the grade level and their competence for science learning increases as the grade level increases. Similar results emerged in the research of Celep Havuz and Karamustafaoglu (2016), who worked with preservice teachers, and concluded that the perception of IBL was significant in favor of the higher classes. As the grad level increases, it can be said that the increase in students' competence for science learning is due to the knowledge and experience that students accumulate at each grade level.

\section{Suggestions}

In the study, it was determined that each subscale of the students' competence for science learning levels was above the average score, but there was a significant difference in terms of gender in favor of females. It is recommended to investigate the causes of this difference, the effect of teacher's role or the effect of factors such as motivation and self-regulation ability. In addition, in the study, it was concluded that the education level of the parents and the student's competence for science learning were related. It is thought that investigating the similarity level of parental education level in different age groups (middle and university) or groups with cognitive differences such as gifted students will provide an opportunity to review the education policy established for IBL in science courses.

It has been determined that the students with high science course achievement have high competence for science learning, scientific inquiry and communication competence, however, as their grade level increases, their competence for science learning decrease. However, due to the limited studies on competence for science learning and communication, researchers working on this subject are advised to focus on primary, middle and university groups. However, the differentiation of teachers' views on this subject was not evaluated in terms of their professional experience. Researchers who will conduct a similar research are advised to consider this variable.

In the results of the research, it was determined that the competence for science learning of male students, students with low parental education level, students with low science course achievement and upper grade students were found to be low, but the reasons for these differences were not investigated. As a result, it is suggested that researchers concentrate on these topics, as well as provide assistance to groups with poor competence for science learning. However, in their research to determine the awareness of science teachers for inquiry-based teaching, Açgöz and Uluçınar-Sağır (2020) determined that teachers do not have a clear knowledge of IBL and that a small number of teachers try to 
apply the inquiry-based teaching approach in their classrooms. The research findings also show that teachers are trying to carry out the inquiry process in their classrooms. However, teachers should put more emphasis on the scientific inquiry and communication subdimensions of IBL in the learning environment to improve students' competence for science learning, guide students with their questions, offer them opportunities to express themselves, create claims and evidence based on the data collected by students, and to create environments where they can discuss and negotiate with their friends.

Ethical Approval: This research was produced from first authors' master's thesis and was carried out with the permission of the Ministry of National Education dated 12/05/2017 and numbered 29409993-605.01-E.6862726.

Conflict Interest: There is no conflict of interest in this study and no financial support has been received.

Authors Contributions: Author contribution is equal.

\section{References}

Abd-El-Khalick, F., Boujaoude, S., Duschl, R., Lederman, N. G., Mamlok-Naaman, R., Hofstein, A. \& Tuan, H. L. (2004). Inquiry in science education: International perspectives. Science Education, 88(3), pp.9-13. https://doi.org/10.1002/sce.10118

Açıkgöz, D. \& Uluçınar Sağır, Ş. (2019). Investıgatıon of science teachers attitudes towards inquiry based teaching. Electronic Journal of Education Sciences, 8(16), 172-187. https://dergipark.org.tr/tr/pub/ejedus/issue/51353/630948

Alemli, A. (2019). Investigation of the effectiveness of research inquiry based learning approach in science education by meta analysis method. Unpublished masters' thesis, Kastamonu University, Social Sciences Institute.

Antink-Meyer, A., Bartos, S., Lederman, J. S., \& Lederman, N. G. (2016). Using science camps to develop understandings about scientific inquiry-Taiwanese students in U.S. summer science camp. International Journal of Science and Mathematics Education, 14(1), 29-53.

Aslan-Efe, H. ve Özmen, S. (2018). Examining secondary school students' competencies for learning science. Journal of Computer and Education Research, 6(11), 88-105. https://doi.org/10.18009/jcer.376953 
Aydın, G. (2016). Reflections of inquiry-based laboratory experiments on prospective teachers' communication skills. International Online Journal of Educational Sciences, 8(2), 49-61. http://dx.doi.org/10.15345/iojes.2016.02.005

Baki, A., \& Gökçek, T. (2012). A general overvıew of mıxed method researches. Elektronik Electronic Journal of Social Sciences, 11(42), 1-21. https://dergipark.org.tr/tr/pub/esosder/issue/6156/82721

Bilir, U. \& Özkan, M. (2018). The effect of inquiry based learning approach for students' academic success in science teaching. Journal of Uludag University Faculty of Education, 31(1), 223-256. https://doi.org/10.19171/uefad.450103

Bybee, R. (2000). Teaching science as inquiry. In J. Minstrell, \& E. van Zee (Eds.), Inquiring into inquiry learning and teaching in science (pp. 20-46). Washington, DC: American Association for the Advancement of Science.

Cairns, D., \& Areepattamannil, S. (2019). Exploring the relations of inquiry-based teaching to science achievement and dispositions in 54 countries. Research in Science Education, 49(1), 1-23. https://doi.org/10.1007/s11165-017-9639-x

Capps, D. K., \& Crawford, B. A. (2013) Inquiry-based instruction and teaching about nature of science: are they happening? Journal of Science Teacher Education, 24(3), 497526. https://doi.org/10.1007/s10972-012-9314-z

Celep Havuz, A. \& Karamustafaoğlu, S. (2016). The investigation of prospective science education teachers' perception related to the inquiry based learning. Amasya Education Journal, 5(1), 233-247.

Chang, H. P., Chen, C. C., Guo, G. J., Cheng, Y. J., Lin, C. Y., \& Jen, T. H. (2011). The development of a competence scale for learning science: Inquiry and communication. International Journal of Science and Mathematics Education, 9(5), 1213-1233.

Creswell, J. W., \& Plano Clark, V. L. (2014). Designing and Conducting Mixed Methods Research. (Second edition). (Ed.: Y. Dede ve S. B. Demir). Ankara: An1.

Dobbler, M., Zward, R. C., Tanis, M., \& Oers, B. (2017). Literature review: The role of the teacher in inquiry-based education. Educational Research Review, 22, 194-214.

Doğan, N., Han-Tosunoglu, Ç., Özer, F. \& Akkan, B. (2020). Middle school students' understanding of scientific inquiry: an investigation of gender, grade level and school 
type. Pamukkale University Journal of Education, 49, 162-189. https://doi.org/10.9779/pauefd.515080

Duban, N. (2008). Conducting science and technology course through inquiry-based learning approach in primary education: An action research. Unpublished doctoral thesis, Anadolu University, Educational Science Institute. Eskişehir.

Duran, M. (2014). Study on 7th grade student's inquiry and communication competencies. Procedia Social and Behavioral Sciences, 116, 4511-4516

Duran, M. (2015). The effect of activities based on inquiry-based learning approach on students inqury learning skills, The Journal of Academic Social Science Studies, 32, $399-420$.

Duran, M. \& Dökme, İ. (2018). The effect of inquiry-based learning approach on conceptual understanding level and some learning outcomes. Trakya Journal of Education, 8(3), 559-577.

Gülhan, F. \& Yurdatapan, M. (2014). Araştırma sorgulamaya dayalı etkinliklerin çevre ile ilgili tutum ve davranışlara etkisi. Mustafa Kemal Üniversitesi Sosyal Bilimler Enstitüsü Dergisi, 11 (27), 237-258

Johnson, R. B., Onwuegbuzie, A., \& Turner, L. (2007). Toward a definition of mixed methods research. Journal of Mixed Methods Research, 1(2), 122-133.

Keçeci, G. (2014). The effects of inquiry-based science teaching on students' science process skills and attitudes. Unpublished doctoral thesis, Firat University, Educational Science Institute.

Kızılaslan, A., Sözbilir, M., \& Yaşar, M. D. (2012). Inquiry based teaching in Turkey: A content analysis of research reports, International Journal of Environmental \& Science, 7(4), 599-617.

Ministry of National Education [MoNE], (2005, 2013, 2018). Fen bilimleri dersi ögretim programı [Science curriculum]. Ankara, Turkey: Talim Terbiye Kurulu Başkanlığı [Regulation of Board of Education].

Ministry of National Education [MoNE], (Temmuz 2020). 2020 Ortaöğretim Kurumlarına İlişkin Merkezi Sınav Raporu, Eğitim Analiz ve Değerlendirme Raporları Serisi [2020 Central Exam Report on Secondary Education Institutions, Education Analysis and Evaluation] No:13, Ankara: MEB Yayınları. 
National Research Council [NRC] (1996). National science education standards. Washington, DC: National Academy Press.

National Research Council [NRC] (2000). Inquiry and the national science education standards. Washington: National Academy Press.

Next Generation Science Standards [NGSS], (2013). Next Generation Science Standards: For states, by states. Washington, DC: National Academies Press. www.nextgenscience.org/next-generation-science-standards

Nunaki, J. H., Damopolii, I., Kandowangko, N. Y., \& Nusantari, E. (2019). The effectiveness of inquiry-based learning to train the students' metacognitive skills based on gender differences. International Journal of Instruction, 12(2), 505-516. https://doi.org/10.29333/iji.2019.12232a

Organization for Economic Cooperation and Development (2005). The definition and selection of key competencies: Executive summary. Paris, France.

Özer, Y., \& An1l, D. (2011). Examining the factors affecting students'science and mathematics achivement with structural equation modelling Hacettepe University Journal of Education, 41, 313-324.

Perry, V. R., \& Richardson, C. P. (2001). "The New Mexico Tech Master of Science teaching program: an exemplary model of inquiry-based learning," 31st Annual Frontiers in Education Conference. Impact on Engineering and Science Education. Conference Proceedings (Cat. No.01CH37193), Reno, NV, USA, 2001, pp. T3E-1, doi: 10.1109/FIE.2001.963917.

Raviv, A., Cohen, S., \& Aflalo, E. (2019). How should students learn in the school science laboratory? the benefits of cooperative learning. Research in Science Education, 49(2), 331-345. https://doi.org/10.1007/s11165-017-9618-2

Sarı, K., \& Şaşmaz Ören, F. (2020). The effect of the inquiry-based learning strategy on academic achievements of the students: A study of meta-analysis. Hacettepe University Journal of Education, 35(3), 540-555. doi: 10.16986/HUJE.2019052510

Schwartz, R. S. (2004). Epistemological views in authentic science practices: A cross discipline comparison of scientists' views of nature of science and scientific inquiry. Unpublished doctoral dissertation, Oregon State University, Corvallis, Oregon. 
Şenler, B. (2014). Turkish adaptation of the competence scale for learning science: Validity and reliability study. Journal of Theory and Practice in Education, 10 (2), 393-407.

Taş, E., Başoğlu, S., Sarıgöl, J., Tepe, B. \& Güler, H. (2019). An analysis of scientific studies related with research- inquiry based learning approach in science education between the years 2008-2018 in Turkey. Ordu University Journal of Social Science Research, 9(1), 69-78.

The National Curriculum in England (2013). Key stages 1 and 2 framework document 31.08 .2020 tarihinde https://assets.publishing.service.gov.uk/government/uploads/system/uploads/attachm ent_data/file/425601/PRIMARY_national_curriculum.pdf adresinden alınmıştır.

Timur, B. \& Kıncal, R. Y. (2010). İlköğretim 7. sınıf fen bilgisi dersinde sorgulamalı öğretimin (inquiry teaching) öğrenci başarısına etkisi. Türk Eğitim Bilimleri Dergisi, $8(1), 4165$.

Tytler, R., \& Hobbs, L. (2011), The Australian science curriculum, Primary and middle years educator, 9(2), 3-10.

Varlı, B. \& Uluçınar Sağır, Ş. (2019). The effect of ınquiry-based teaching on secondary school students' science success, questioning perception and metacognitive awareness. Gazi University Journal of Gazi Educational Faculty, 39(2), 703-725.

Wildan, W., Hakim, A., Siahaan, J., \& Anwar, Y. A. S. (2019). A stepwise inquiry approach to improving communication skills and scientific attitudes on a biochemistry course. International Journal of Instruction, 12(4), 407-422. https://doi.org/10.29333/iji.2019.12427a

Wolf, S. J., \& Fraser, B. J. (2008). Learning environment, attitudes and achievement among middle-school science students using inquiry-based laboratory activities. Research in Science Education, 38, 321-341. https://doi.org/10.1007/s11165-007-9052-y

Wu, H. K., \& Krajcik J. S. (2006). Inscriptional practices in two inquiry-based classrooms: A case study of seventh graders' use of data tables and graphs. Journal of Research in Science Teaching, 43(1), 63-95.

Yıldırım, A. \& Şimşek, H. (2018). Qualitative research methods in the social sciences. 11. Edition. Ankara: Seçkin. 